\title{
Izborno zakonodavstvo u Bosni i Hercegovini u kontekstu prakse Evropskog suda za ljudska prava i Ustavnog suda Bosne i Hercegovine
}

\author{
Miodrag N. Simović \\ Redovni član Akademije nauka i umjetnosti Bosne i Hercegovine, \\ sudija Ustavnog suda Bosne i Hercegovine i \\ redovni profesor Pravnog fakulteta Univerziteta u Banjoj Luci \\ miodrag.Simovic@ustavnisud.ba
}

Milena Simović

Redovna profesorica

Fakulteta za bezbjednost i zaštitu

Nezavisnog univerziteta u Banjoj Luci

milena.s@blic.net

Sažetak: Ustavno političko pravo građana je da konstituišu organe vlasti u političkim zajednicama putem izbora. Izbornost daje legitimitet zakonodavnom tijelu kao najširem neposredno izabranom predstavništvu građana. Činom izbora građani neposredno iskazuju svoje povjerenje u vlast koju konstituišu. Izbori su put sticanja, odnosno gubitka legitimiteta. Mogućnost učešća građana u izboru organa vlasti garantuje izborno pravo, što pretpostavlja postojanje, prije svega, višestranačkog sistema, jer u jednopartijskom sistemu građani, praktično, ne vrše izbor, već plebiscitarno glasaju. Međutim, izborni sistem je dio političkog sistema i, po pravilu, dijeli njegovu sudbinu. Pri svemu tome, važan aspekt u posmatranju uloge i dejstva izbornog sistema predstavlja usaglašenost izbornog sistema koji uspostavljaju ustav, zakoni i drugi propisi i onog izbornog sistema koji stvarno funkcioniše u praksi. To pretpostavlja postojanje kontrole (od strane zakonom određenih organa) poštovanja svih izbornih principa i pravila i sankcionisanje svih povreda koje narušavaju izborni sistem i izborni proces.

Moderna ustavna država zasnovana je na suverenosti naroda i vladavini prava, a izbori su spona ta dva stuba moderne države. Kao i svako pravo, tako i izborno pravo može biti povrijeđeno, pa je zaštita tog prava još jedan važan preduslov njegovog ostvarivanja. Ovo pitanje ima širi konstitucionalni značaj, koje komparativna ustavna praksa rješava na različite načine. Pravo da se bira i bude izabran nije apsolutno pravo i državi se priznaje široko polje procjene u pogledu načina na koji će urediti to pitanje, kao i pitanje organizovanja i provođenja izbornog procesa. Obaveza države, koja proističe iz člana 3 Protokola broj 1 uz Evropsku konvenciju za zaštitu ljudskih prava i osnovnih sloboda, predviđa aktivno i pasivno biračko pravo naroda: aktivno pravo glasanja na izborima i pasivno pravo da se učestvuje kao kandidat na izborima. Međutim, ova prava se odnose samo na izbor ,zakonodavnih tijela“. Evropski sud za ljudska prava ima dosljedno mišljenje da se ovaj član primjenjuje samo u odnosu na izbor tijela koja vrše značajnu zakonodavnu funkciju. Da li određeno tijelo vrši 
dovoljnu zakonodavnu vlast da bi u ovu svrhu moglo da se smatra zakonodavnim tijelom, pitanje je procjene na koje treba da se odgovori u svjetlu uloge tog tijela i njegovog doprinosa demokratskoj izradi zakona u kontekstu ustava u cjelini.

Član I/2 Ustava Bosne i Hercegovine utvrđuje da je Bosna i Hercegovina „demokratska država, koja funkcioniše na principu vladavine prava i na osnovu slobodnih i demokratskih izbora" iz kojeg slijedi princip vladavine prava prema kojem svi ustavi, zakoni i drugi propisi koji se donose moraju da budu usklađeni sa ustavnim principima. U tom kontekstu, treba podsjetiti da države uživaju široko polje procjene u uspostavljanju i regulisanju izbornog sistema koji će primjenjivati. Postoje različiti načini organizovanja i sprovođenja izbora, a ova različitost uslovljena je, između ostalog, i političkim razvojem zemlje. Zbog toga, zakonodavstvo koje reguliše izbore mora da bude sagledano u svjetlu političkog razvoja zemlje koja je u pitanju. Nadalje, prema opštem principu demokratije, pravo na demokratsko odlučivanje ostvaruje se legitimnim političkim predstavljanjem koje mora da bude zasnovano na demokratskom izboru onih koje predstavlja i čije interese zastupa. U tom smislu veza između onih koje predstavlja i njihovih političkih predstavnika na svim administrativno-političkim nivoima je ta koja omogućava legitimitet predstavnicima zajednice. Dakle, samo legitimitet predstavljanja stvara osnov za stvarno učestvovanje i odlučivanje.

Izborni zakon BiH usvojen je 2001. godine od kada je u više navrata pretrpio izmjene i dopune, čemu je razlog, između ostalog, bio i složen ustavni, institucionalni i politički koncept u Bosni i Hercegovini. Izborni zakon BiH, kako je to propisano odredbom člana 1.1, propisuje izbore na državnom nivou $i$, utvrđuje principe za provođenje izbora na svim nivoima vlasti u Bosni i Hercegovini“.. Prema ocjenama različitih međunarodnih organizacija i institucija (npr. OSCE i Venecijanska komisija), Izborni zakon BiH je sveobuhvatan i, generalno, propisuje čvrstu osnovu za provođenje demokratskih izbora. S druge strane, s obzirom na broj i prirodu zakona koji se primjenjuju u vezi s izborima, te imajući na umu kompleksno pravno uređenje u Bosni i Hercegovini, pravni okvir za provođenje izbora u Bosni i Hercegovini takođe može da se smatra kompleksnim. Naime, osim Izbornog zakona BiH, postoje i Izborni zakon Republike Srpske i Izborni zakon Brčko distrikta BiH, dok je u Federaciji BiH donesen Zakon o osnivanju organa za provođenje izbora u Federaciji BiH. Zbog toga, postoji naročita potreba da, s ciljem da se provedu fer i demokratski izbori, kompleksni izborni legislativni okvir bude harmonizovan i da svi zakoni u toj oblasti slijede osnovne principe i standarde utvrđene Izbornim zakonom BiH

Ključne riječi: izbori, izborni sistem, biračko pravo, ustavno političko pravo

\section{Uvodne napomene}

Tekst alineje 9 Preambule Ustava BiH utvrđuje da „,...Bošnjaci, Hrvati i Srbi, kao konstitutivni narodi (zajedno sa ostalima) i građani Bosne i Hercegovine ovim odlučuju da Ustav BiH glasi. “Nadalje, član IV/1 Ustava BiH utvrđuje da se „Dom naroda sastoji od 15 delegata, od kojih su dvije trećine iz Federacije (pet Hrvata i pet Bošnjaka) i jedna trećina iz Republike Srpske (pet Srba). a) Imenovane hrvatske i bošnjačke delegate iz Federacije biraju hrvatski, odnosno bošnjački delegati u Domu naroda Federacije. Delegate iz Republike Srpske bira Narodna skupština Republike Srpske. b) Devet članova Doma 
Miodrag N. Simović, Milena Simović: Izborno zakonodavstvo u Bosni i Hercegovini u kontekstu prakse...

naroda predstavljaju kvorum, pod uslovom da su prisutna najmanje tri bošnjačka, tri hrvatska i tri srpska delegata.“ Osim toga, dio teksta člana V/4b) Ustava BiH glasi da ,...Predsjedavajući imenuje i zamjenike ministara (koji nisu iz istog konstitutivnog naroda)“", te dio teksta člana VII/2 Ustava $\mathrm{BiH}$ da „Prvi Upravni odbor Centralne banke sačinjavaće guverner, kojeg imenuje Međunarodni monetarni fond nakon konsultacija sa Predsjedništvom i tri člana koja imenuje Predsjedništvo, od kojih su dva iz Federacije (jedan Bošnjak i jedan Hrvat, koji zajedno imaju jedan glas) i jedan iz Republike Srpske...".

Opšti princip demokratije podrazumijeva da vlast u državi proističe iz naroda i pripada narodu (Đukić-Veljović, 1995: 56-57). Iz Ustava BiH slijedi da je Ustav BiH kao narod označio konstitutivne narode koji zajedno sa Ostalima i građanima Bosne i Hercegovine čine zajednicu državljana koja ravnopravno ostvaruje vlast putem svojih predstavnika, a pravo na demokratsko odlučivanje ostvaruje se legitimnim političkim predstavljanjem koje mora biti zasnovano na demokratskom izboru te zajednice državljana koju predstavlja i čije interese zastupa. Međutim, iz navedene alineje Preambule Ustava BiH slijedi da je ustavotvorac imenovao, odnosno označio konstitutivne narode (Bošnjake, Srbe i Hrvate) kao posebne kolektivitete i priznao im jednaka prava, tj. da je ,podvukao“ poseban, ravnopravan i jednak status Bošnjaka, Hrvata i Srba kao konstitutivnih naroda. S tim u vezi, Ustavni sud Bosne i Hercegovine ${ }^{1}$ je u svojoj Odluci broj U 5/98 (odluka o konstitutivnosti) istakao: „Ovo označavanje u Preambuli, stoga, mora biti shvaćeno kao jedan natkrovljujući princip Ustava $\mathrm{BiH}$ kojem se entiteti moraju u potpunosti povinovati prema članu III/3(b) Ustava $\mathrm{BiH}^{\text {“. }}$. Pored navedenog, iz navedenih odredaba Ustava $\mathrm{BiH}$ slijedi da je ustavotvorac u institucijama Bosne i Hercegovine uspostavio proporcionalnu zastupljenost Bošnjaka, Srba i Hrvata kao konstitutivnih naroda.

Izborni zakon $\mathrm{BiH}^{2}$ je temeljni zakon kojim se utvrđuju ne samo izbori za državne organe vlasti, već i principi na kojima moraju da budu zasnovani

\footnotetext{
${ }^{1}$ U daljem tekstu: Ustavni sud.

${ }^{2}$ Tehnički prečišćeni tekst. Ovaj tehnički prečišćeni tekst sadrži osnovni tekst Izbornog zakona BiH („Službeni glasnik BiH“, broj 23/01), te Odluku o izmjenama i dopunama Izbornog zakona BiH („Službeni glasnik $\mathrm{BiH}^{\prime}$, broj 7/02), Odluku o izmjenama i dopunama Izbornog zakona BiH (,Službeni glasnik $\mathrm{BiH}^{\prime}$, broj 9/02), Zakon o izmjenama i dopunama Izbornog zakona $\mathrm{BiH}$ („Službeni glasnik BiH“, broj 20/02), Ispravku Zakona o izmjenama i dopunama Izbornog zakona BiH („Službeni glasnik BiH“", broj 25/02), Zakon o izmjenama i dopunama Izbornog zakona BiH („Službeni glasnik BiH“, broj 4/04), Zakon o izmjenama i dopunama Izbornog zakona BiH (,Službeni glasnik BiH“, broj 20/04), Zakon o izmjenama i dopunama Izbornog zakona BiH (,Službeni glasnik BiH“, broj 25/05), Zakon o izmjenama i dopunama Izbornog zakona BiH (,Službeni glasnik BiH“, broj 52/05), Ispravku Zakona o izmjenama i dopunama Izbornog zakona BiH (,Službeni glasnik BiH“, broj 65/05), Zakon o izmjenama i dopunama Izbornog zakona $\mathrm{BiH}$ (,Službeni glasnik BiH“, broj 77/05), Zakon o izmjenama i dopunama
} 
izborni zakoni i propisi na ostalim nivoima vlasti (Ćeranić, 2012: 162-179). Prvo pitanje koje se postavilo pred Ustavni sud jeste da li neusklađenost odredaba osporenog zakona koji je donijela entitetska skupština vodi inkompatibilnosti sa Ustavom $\mathrm{BiH}$, u prvom redu s članom $\mathrm{III} / 3$ b) Ustava $\mathrm{BiH}$, a shodno tome i s principom vladavine prava iz člana $\mathrm{I} / 2$ Ustava $\mathrm{BiH}$. U vezi s ovim, Ustavni sud je dao odgovor u svojoj praksi. Naime, u svojoj Odluci broj U-14/04 Ustavni sud je usvojio principijelan stav da „donošenje entitetskih zakona suprotno proceduri koja je propisana državnim zakonima - pokreće pitanje ustavnosti takvih zakona u smislu odredaba člana III/3b) Ustava $\mathrm{BiH}$, te da se obaveze koje nameću državni zakoni moraju poštovati““3. Ovaj stav Ustavni sud je reafirmisao i u Odluci broj U-2/11 u kojoj je ponovo istakao da se ,zakoni BiH koje je usvojila Parlamentarna skupština BiH smatraju [...] odlukama institucija $\mathrm{BiH}$ ' iz člana III/3b) Ustava $\mathrm{BiH}^{\prime}$, te donošenje zakona od entitetā ili drugih administrativnih jedinica u Bosni i Hercegovini, suprotno proceduri koju propisuju državni zakoni, može da dovede u pitanje poštovanje odredaba člana III/3b) Ustava $\mathrm{BiH}$, shodno kojima su entiteti i druge administrativne jedinice u $\mathrm{BiH}$ dužni da se pridržavaju, između ostalog, (i) odluka institucija $\mathrm{BiH}$.

Kada bi se smatralo suprotno, osim što bi se u potpunosti doveo u pitanje autoritet institucija $\mathrm{BiH}$, doveo bi se u pitanje i princip iz člana $\mathrm{I} / 2$ Ustava BiH prema kojem će „Bosna i Hercegovina biti demokratska država koja će funkcionisati prema slovu zakona...". U tom slučaju s pravom bi moglo da se postavi pitanje svrhe državnih zakona (npr. zakona u oblasti privatizacije, zatim, rada osiguravajućih društava, indirektnog oporezivanja i sl.) ako bi entiteti ili druge administrativne jedinice $\mathrm{BiH}$ mogli da donose zakone kojima se krše ili izbjegavaju obaveze koje se entitetima ili drugim administrativnim jedinicama $\mathrm{BiH}$ nalažu odredbama državnih zakona, tj. zakona donesenih na nivou institucija BiH. Dakle, entiteti (ili druge administrativne jedinice $\mathrm{BiH})$ moraju da poštuju obaveze koje im se nalažu zakonima koje su donijele

\footnotetext{
Izbornog zakona BiH (,Službeni glasnik BiH“, broj 11/06), Zakon o izmjenama i dopunama Izbornog zakona BiH (,,Službeni glasnik BiH“, broj 24/06), Zakon o usvajanju Zakona o izmjenama i dopunama Izbornog zakona $\mathrm{BiH}$ (,Službeni glasnik $\mathrm{BiH}^{\prime}$, broj 32/07), Zakon o izmjenama i dopunama Izbornog zakona BiH („Službeni glasnik BiH“, broj 33/08), Zakon o izmjenama i dopunama Izbornog zakona BiH („Službeni glasnik BiH“, broj 37/08), Zakon o izmjenama i dopunama Izbornog zakona BiH („Službeni glasnik BiH“, broj 32/10), Zakon o izmjenama i dopunama Izbornog zakona BiH („Službeni glasnik BiH“, broj 18/13); Zakon o izmjeni i dopuni Izbornog zakona BiH (,,Službeni glasnik BiH“ broj 7/14) i Zakon o izmjenama i dopunama Izbornog zakona BiH (,Službeni glasnik BiH“ broj 31/16).

${ }^{3}$ Vidi, mutatis mutandis, Ustavni sud, Odluka o dopustivosti i meritumu broj U-14/04 od 29. oktobra 2010. godine, objavljena u „Službenom glasniku $\mathrm{BiH}^{\circ}$ broj 23/05.
} 
Miodrag N. Simović, Milena Simović: Izborno zakonodavstvo u Bosni i Hercegovini u kontekstu prakse...

institucije Bosne i Hercegovine. Činjenica da te obaveze nisu ispoštovane može da dovede do kršenja odredaba Ustava $\mathrm{BiH} .{ }^{\text {“4 }}$

\section{Nadležnost Ustavnog suda}

U odnosu na odredbe Izbornog zakona, iako odredba člana VI/3a) Ustava $\mathrm{BiH}$ ne predviđa eksplicitnu nadležnost Ustavnog suda da ocjenjuje ustavnost zakona ili odredbe zakona $\mathrm{BiH}$, supstancionalni pojam ovlašćenja određenih samim Ustavom BiH sadrži u sebi titulu s Ustavnom sudu za takvu nadležnost, a posebno ulogom Ustavnog suda kao tijela koje podržava Ustav $\mathrm{BiH}$ (Đukić-Veljović, Vuković, 2006: 1398). Stanovište Ustavnog suda u ovakvim slučajevima u njegovoj dosadašnjoj praksi jasno ukazuje da je Ustavni sud nadležan da ocjenjuje ustavnost zakona, odnosno pojedinih odredbi zakona $\mathrm{BiH}^{5}$ (Stojanović, 2012: 26-50).

U pogledu nadležnosti Visokog predstavnika za BiH da donosi zakone, te nadležnosti Ustavnog suda da odlučuje o saglasnosti tih zakona sa Ustavom $\mathrm{BiH}$, Ustavni sud je već ranije izrazio svoj stav da ovlašćenja Visokog predstavnika za BiH proizilaze iz Aneksa X Opšteg okvirnog sporazuma za mir u $\mathrm{BiH}$, relevantnih rezolucija Savjeta bezbjednosti Ujedinjenih nacija i Bonske deklaracije i da ta ovlašćenja, kao ni vršenje tih ovlašćenja, nisu podložne kontroli Ustavnog suda. Međutim, kada Visoki predstavnik interveniše u pravni sistem $\mathrm{BiH}$, supstituišući domaće vlasti, tada djeluje kao vlast, a zakoni koje donosi su prirode domaćih zakona, te moraju da se smatraju zakonima $\mathrm{BiH}$, čija je saglasnost sa Ustavom BiH podložna kontroli Ustavnog suda ${ }^{6}$.

Također, u pogledu odredbi statuta gradova i opština, Ustavni sud je u svojoj praksi već elaborirao pitanje svoje nadležnosti iz člana VI/3a) Ustava BiH kada je predmet ocjene bio Statut Grada Sarajeva i zaključio da je „kao institucija koja podržava Ustav $\mathrm{BiH}$, nadležan da ispituje ustavnost svih akata, bez obzira na donosioca, ako je pitanje pokrenuto prema jednoj od nadležnosti Ustavnog suda iz člana VI/3 Ustava BiH. U skladu s argumentacijom o ljudskim pravima, Ustavni sud je mišljenja da, kad god je to moguće, mora da

\footnotetext{
${ }^{4}$ Vidi Ustavni sud, Odluka o dopustivosti i meritumu broj U-2/11 od 27. maja 2011. godine, tačka 52, objavljena u „Službenom glasniku BiH“ broj 99/11.

${ }^{5}$ Vidi Ustavni sud, Odluka broj U-1/99 od 14. avgusta 1999. godine, ,Službeni glasnik BiH“ broj 16/99 i Odluka broj U-14/02 od 30. januara 2004. godine, „Službeni glasnik BiH“ broj 18/04.

${ }^{6}$ Vidi Ustavni sud, Odluka broj U-9/00 od 3. novembra 2000. godine, objavljena u „Službenom glasniku BiH“ broj 1/01, Odluka broj U-16/00 od 2. februara 2001. godine, objavljena u „Službenom glasniku $\mathrm{BiH}^{\prime}$ “ broj 13/01 i Odluka broj U-25/00 od 23. marta 2001. godine, objavljena u „Službenom glasniku $\mathrm{BiH}^{\prime \prime}$ broj 17/01.
} 
interpretira svoju jurisdikciju tako da dozvoli najširu mogućnost otklanjanja posljedica kršenja tih prava. U konkretnom slučaju, zahtjev za ocjenu ustavnosti se upravo odnosi na pitanja koja proizilaze iz Ustava $\mathrm{BiH}$ i međunarodnih sporazuma kojima se garantuje zaštita ljudskih prava i tiče se ostvarivanja ljudskih prava i ustavnih principa, kao što je princip konstitutivnosti naroda i pravo na zabranu diskriminacije ${ }^{67}$. Rukovodeći se principima iz navedene odluke, Ustavni sud smatra da je u konkretnom slučaju nadležan da ispituje ustavnost Statuta, budući da se i ovdje radi o zahtjevu za ocjenu ustavnosti koji se odnosi na pitanja koja proizilaze iz Ustava $\mathrm{BiH}$ i međunarodnih sporazuma o zaštiti ljudskih prava, odnosno zaštiti ljudskih prava i prava na zabranu diskriminacije.

S obzirom na veoma ograničen djelokrug zakonodavne vlasti koju vrši gradsko vijeće, Ustavni sud smatra da je gradsko vijeće uglavnom administrativno, a ne zakonodavno tijelo. Shodno tome, izbor za gradsko vijeće ne potpada u djelokrug obaveze BiH prema članu 3 Protokola broj 1 uz Evropsku konvenciju za zaštitu ljudskih prava i osnovnih sloboda ${ }^{8}$ da održi slobodne izbore koji će obezbijediti ,slobodno izražavanje mišljenja naroda pri izboru zakonodavnih tijela“. S obzirom na ovo, zahtjev ne pokreće pitanje u pogledu primjene člana 14 Evropske konvencije u vezi s članom 3 Protokola broj 1 uz Evropsku konvenciju. Stoga je ovaj dio zahtjeva odbijen kao neosnovan.

\section{Međunarodni standardi}

Izvori međunarodnog prava ljudskih i izbornih prava, putem pravnih normi koje sadrže i ustanova koje se na osnovu njih formiraju, uspostavljaju sisteme zaštite ljudskih prava (Pajvančić, Vukčević, 2012: 106-108; Pajvančić, 2012:11-26). Danas je najznačajniji sistem zaštite koji je formiran pod okriljem OUN, a pored tog, univerzalnog sistema postoje i regionalni aranžmani, formirani za posebne oblasti, od kojih su za BiH značajni sistemi zaštite uspostavljeni na evropskom kontinentu, a to su sistemi zaštite pod okriljem Savjeta Evrope, Organizacije za evropsku bezbjednost i saradnju (OEBS-a) i Evropske unije (EU) (Pajvančić, 2008: 94-96; Pajvančić, 2003a: 98-107).

U sistemu ljudskih prava OUN najznačajniji izvori ljudskih i izbornih prava su: Univerzalna deklaracija o ljudskim pravima iz 1948. godine i Međunarodni

\footnotetext{
${ }^{7}$ Vidi Ustavni sud, Odluka o dopustivosti i meritumu, broj U-4/05 od 22. aprila 2005. godine, st. 14 do 17, objavljena u „Službenom glasniku BiH“ broj 32/05.

${ }^{8}$ Convention for the Protection of Human Rights and Fundamental Freedoms, usvojena u Rimu, 4. novembra 1950. godine, stupila je na snagu 3. septembra 1953. godine, nakon deponovanja desetog instrumenta ratifikacije, shodno članu 59 Konvencije.U daljem tekstu: Evropska konvencija.
} 
Miodrag N. Simović, Milena Simović: Izborno zakonodavstvo u Bosni i Hercegovini u kontekstu prakse...

pakt o građanskim i ljudskim pravima iz 1966. godine ${ }^{9}$ (Breneselović, 2012: 232-239).

Univerzalna deklaracija o ljudskim pravima je soft law izvor prava, ali je uprkos tome imala značajan odjek u svijetu, jer je pod njenim uticajem veliki broj država u svoje ustave ugradio identičnu listu ljudskih prava, a tu listu preuzeli su i brojni međunarodni dokumenti. Deklaracija proklamuje veći broj građanskih i političkih prava, a za izborno pravo je najznačajniji član 21 , prema kome „svako ima pravo da učestvuje u upravljanju svojom zemljom, neposredno ili preko slobodno izabranih predstavnika. Svako ima pravo da na ravnopravnoj osnovi stupa u javnu službu u svojoj zemlji“ (Horowitz, 2003: 115-127). Volja naroda je osnova državne vlasti: ova volja treba da se izražava na povremenim i slobodnim izborima, koji će se sprovoditi opštim i jednakim pravom glasa, tajnim glasanjem ili odgovarajućim postupkom kojim se obezbjeđuje sloboda glasanja.

Međunarodni pakt, slično Deklaraciji, ustanovljava kodeks građanskih i političkih prava ali, za razliku od nje, pravno obavezuje države koje su mu pristupile, pa predstavlja hard law izvor prava. Članom 25 propisano je da građani imaju pravo da učestvuju u vođenju javnih poslova, neposredno ili preko slobodno izabranih predstavnika, kao i pravo da biraju i budu birani na pravednim povremenim izborima sa opštim i jednakim pravom glasa i tajnim glasanjem. Ovu, opštu garanciju izbornog prava dopunjuje načelo nediskriminacije po osnovu rase, boje kože, pola, jezika, vjeroispovijesti, političkog ili drugog mišljenja, nacionalnog ili društvenog porijekla, imovine, rođenja ili drugog statusa (član 2 stav 1), kao i pravilo da ovo pravo građana ne može biti podvrgnuto neumjesnim ograničenjima ${ }^{10}$ [član 25 stav 1 tačka b)]. Pored toga, članom 3 Pakta predviđeno je i dodatno nediskriminaciono načelo ${ }^{11}$, po kome su države članice dužne da osiguraju jednako pravo muškaraca i žena na uživanje svih građanskih i političkih prava utvrđenih u Paktu ${ }^{12}$ (Jovičić, Plavšić-Nešić, 2012: 208-231).

\footnotetext{
${ }^{9} \mathrm{U}$ daljem tekstu: Međunarodni pakt.

${ }^{10}$ Komitet za ljudska prava je dao bliže sadržinsko određenje termina „neumjesna ograničenja“ ukazujući da pod tim treba smatrati svako ograničenje koje nije obrazloženo.

${ }^{11}$ Ovo načelo je akcesorno s obzirom na to da se realizuje isključivo u okviru pozivanja na povredu nekog od ljudskih prava koja su priznata Paktom, ne i samostalno.

${ }^{12}$ Svaka država koja je postala članica Pakta je samim tim prihvatila obavezu da poštuje prava u njemu proklamovana, što uključuje i obavezu da Komitetu za ljudska prava (koji je ustanovljen članom 28, kao tijelo koje čine nezavisni eksperti za oblast ljudskih prava, čiji je osnovni zadatak da nadgleda implementaciju Pakta od strane država članica) podnosi periodične izvještaje, uobičajeno jednom u pet godina, o mjerama koje je usvojila radi omogućavanja ostvarivanja prava koja su Paktom priznata (član 40). Pored toga, Komitetu se mogu obratiti i države sa odgovarajućim saopštenjima kojima se ukazuje na nepoštovanje ljudskih prava, odnosno neispunjavanje obaveza predviđenih Paktom od strane druge
} 
Univerzalni sistem ljudskih prava OUN-a potvrđuje i promoviše evropski sistem zaštite ljudskih prava, u kome su najznačajniji sljedeći dokumenti: Evropska konvencija za zaštitu ljudskih prava i osnovnih sloboda od 1950. godine, Završni dokument Konferencije za evropsku bezbjednost i saradnju (KEBS-a) - (OEBS) iz Kopenhagena od 1990. godine i ugovori o osnivanju Evropske unije.

U uvodnoj rečenici Evropska konvencija se poziva na Univerzalnu deklaraciju o ljudskim pravima, a u članu 1 zahtijeva od država članica da svakome u njihovoj nadležnosti garantuju prava i slobode koje se njim uređuju ${ }^{13}$. Ovaj međunarodni ugovor uređuje standardna građanska i politička prava, odnosno prava koja promoviše prvih 21 članova Univerzalne deklaracije o ljudskim pravima (Đurić, 2012:133-161). Konvencija je do sada novelirana sa 16 protokola, od kojih je za izborno pravo posebno značajan Prvi protokol ${ }^{14}$, koji u članu 3 propisuje: „Visoke strane ugovornice se obavezuju da u primjerenim vremenskim razmacima održavaju slobodne izbore sa tajnim glasanjem, pod uslovima koji obezbjeđuju slobodno izražavanje mišljenja naroda pri izboru zakonodavnih tijela“. Konvencijom je osnovan Evropski sud za ljudska prava $^{15}$, kome se građani mogu neposredno obraćati sa svojim zahtjevima ako smatraju da su im povrijeđena ljudska prava, ali „,...tek kad se iscrpe svi unutrašnji pravni lijekovi, u skladu sa opštepriznatim načelima međunarodnog prava..." (član 35) ${ }^{16}$. Praksa ovog suda pokazuje da on uspješno funkcioniše, što potvrđuje da se uređenje i obezbjeđivanje ostvarivanja ljudskih prava može uspješno organizovati i na međunarodnom nivou.

U okviru OEBS-a je usvojeno nekoliko završnih dokumenata od značaja za ljudska i izborna prava, među kojima posebno mjesto pripada Dokumentu

\footnotetext{
države članice, pod uslovom da su obje države priznale nadležnost Komiteta da prima i razmatra takva saopštenja (član 41).

${ }^{13}$ Prava i slobode su sistematizovane u dio I Konvencije i države članice su prihvatile da poštuju tu listu prava, da je implementiraju u odgovarajuće unutrašnje akte, kao i da obezbijede sprovođenje zaštite ljudskih prava u okviru unutrašnjeg sistema sudske zaštite.

${ }^{14}$ Stupio je na snagu 18. maja 1954. godine poslije deponovanja deset instrumenata ratifikacije, u skladu sa članom 6.

${ }^{15} \mathrm{U}$ daljem tekstu: Evropski sud. Sistem sudske zaštite uspostavljen Konvencijom je originalno predviđao paralelno Komisiju za ljudska prava i Sud za ljudska prava, pri čemu je Komisija bila nadležna za prijem zahtjeva kojima se ukazivalo na povrede ljudskih prava jer su samo oni zahtjevi, koje bi Komisija ocijenila osnovanim, prosljeđivani Sudu. Međutim, stupanjem na snagu 11-og protokola uz Konvenciju (1998.), ta komisija je ukinuta i od tada se svi zahtjevi podnose direktno Evropskom sudu za ljudska prava.

${ }^{16}$ Isto pravo imaju i države kada smatraju da su u drugoj državi članici povrijeđene neke odredbe Konvencije, što je predviđeno članom 33.
} 
iz Kopenhagena od 1990. godine ${ }^{17}$ (Popović, 2011: 343-357). U njemu se predviđa da „,među elementima pravde koji su ključni za potpuno ispoljavanje urođenog dostojanstva i jednakih i neotuđivih prava svih ljudskih bića ... spadaju slobodni izbori koji će se održavati u primjerenim vremenskim razmacima putem tajnog glasanja ili odgovarajućim postupkom kojim se obezbjeđuje sloboda glasanja, pod uslovima koji obezbjeđuju slobodno izražavanje mišljenja naroda pri izboru njihovih predstavnika“18 (Milenković, 2012: 180207). U paragrafu 6 se posebno predviđa da volja naroda, slobodno i pošteno izražena na periodičnim i istinskim izborima, predstavlja osnov autoriteta $i$ legitimiteta svake vlasti (Ćirić, 2012: 51-75). Principi koje promoviše ovaj dokument imaju za cilj da podrže i unaprijede vladavinu prava i ograničenje vlasti jer, kako se to ističe u paragrafu 1, zaštita i unapređenje ljudskih prava i osnovnih sloboda su neki od osnovnih ciljeva vlasti, zbog čega priznanje tih prava čini osnovu slobode, pravde i mira.

Evropska unija, takođe, u svojim aktima podržava univerzalnost i neotuđivost ljudskih prava, demokratiju i vladavinu prava (Milošević, 2007: 2337). Član 6 Ugovora o osnivanju Evropske unija iz 1992. godine ${ }^{19}$ potvrđuje da Evropska unija počiva na principima slobode, demokratije, poštovanja ljudskih prava i vladavine prava, te da su to osnovne evropske vrijednosti zajedničke svim državama članicama ${ }^{20}$. Na samitu održanom u Nici 2000. godine Evropska unija je usvojila Povelju o osnovnim pravima Evropske uni$\mathrm{je}^{21}$, kojom se uređuje set ljudskih i građanskih socijalnih i političkih prava ${ }^{22}$, od kojih je većina već obuhvaćena u raznim dokumentima Unije, ali su sada po prvi put sistematizovana u okviru jednog dokumenta. Riječ je, u osnovi, o istim pravima koja promoviše Evropska konvencija ${ }^{23}$, ali je ta lista proširena i nekim novim pravima, kao naprimjer, političkim pravima državljana Evropske unije, pravom na dobru administraciju, socijalnim pravima radnika i dr. Razrada biračkog prava je izvršena u okviru Glave V Povelje, koja nosi

\footnotetext{
${ }^{17}$ Document of the Copenhagen Meeting of the Conference on the Human Dimension of the Conference on Security and Cooperatiion in Europe, od 29. juna 1990. godine. Za izborno pravo posebno su značajni član 6 i dalje.

${ }^{18}$ Paragrafi 5 i 5.1 Završnog dokumenta iz Kopenhagena.

${ }^{19}$ Treaty on European Union (Official Journal C 191, 29 July 1992), zaključen u Mastrihtu, potpisan 1992., a stupio na snagu 1993. godine.

${ }^{20}$ Poštovanje ovih principa zahtijeva se i od država koje pretenduju da postanu članice Unije, što je izričito predviđeno članom 49 Ugovora.

${ }^{21}$ Charter of Fundamental Rights of the European Union (Official Journal C 364/1, 18 December 2000). Ova povelja je pravni akt u formi političke deklaracije (soft law izvor prava) i nije pravno obavezujuća.

${ }^{22}$ Ova prava su grupisana $u$ šest poglavlja: dostojanstvo, slobode, jednakost, solidarnost, prava građana i pravda.

${ }^{23}$ Evropska unija nije potpisnica ove konvencije, tako da ona nije izvor prava u Uniji.
} 
naslov „Prava građana“, tako što se posebno uređuje biračko pravo na izborima za Evropski parlament (član 39) i biračko pravo na lokalnim - komunalnim izborima (član 40) $)^{24}$.

Prava promovisana Poveljom o osnovnim pravima Evropske unije potvrdio je i Ustav Evropske unije od 18. juna 2004. godine ${ }^{25}$, koji u Dijelu II preuzima njen tekst ${ }^{26}$. Ovaj ustav, međutim, nije prihvaćen ${ }^{27}$, već je reformisan ugovorom zaključenim 2007. godine u Lisabonu ${ }^{28}$ koji, takođe, preuzima Povelju o osnovnim pravima kao svoj sastavni dio ${ }^{29}$, pa je stupanjem Lisabonskog ugovora na snagu Povelja, konačno, postala pravno obavezujuća.

Član II/4 Ustava BiH utvrđuje da se uživanje prava i sloboda, predviđenih u međunarodnim sporazumima navedenim u Aneksu I Ustava BiH, obezbjeđuje svim licima bez diskriminacije prema bilo kojem osnovu. U Aneksu I tačka 7 Ustava BiH - Dodatni sporazumi o ljudskim pravima koji će se primjenjivati u Bosni i Hercegovini je, između ostalog, naveden i Međunarodni pakt o građanskim i političkim pravima (1966). Praksa je Evropskog suda da diskriminacija postoji samo ako se lice ili grupa lica koji se nalaze u analognoj situaciji različito tretiraju, a ne postoji neko objektivno i razumno opravdanje za različit tretman ${ }^{30}$. Ovaj pristup je Evropski sud primijenio na pitanja diskriminacije u vezi s učešćem u političkom životu u Bosni i Hercegovini u

\footnotetext{
${ }^{24}$ Pravilo je da je svakom građaninu Unije priznato aktivno i pasivno biračko pravo na izborima za Evropski parlament $u$ državi u kojoj ima prebivalište, pod jednakim uslovima kao državljani te države, $i$ to na neposrednim, slobodnim i tajnim izborima sa opštim pravom glasa. Ista prava građanima Unije priznata su i kada se radi o lokalnim izborima u državi članici.

${ }^{25} \mathrm{U}$ pitanju je Prijedlog Ugovora o Ustavu Evropske unije (Treaty Establishing a Constitution for Europe, „Official Journal“ 2004/C 310/01, 16 December 2004), koji je trebalo da zamijeni sve postojeće ugovore.

${ }^{26}$ Osim na Povelju, Ustav Evropske unije se poziva i na Evropsku konvenciju i izričito navodi da pristupanje toj konvenciji ne utiče na nadležnost Unije definisanu u njenom Ustavu (član I-9 Ustava, koji je sistematizovan u okviru Glave 2: Osnovna prava i državljanstvo Unije).

${ }^{27}$ Evropski Ustav su na referendumima održanim 2005. godine odbacile Holandija i Irska.

${ }^{28}$ Lisabonskim ugovorom se predviđaju izmjene i dopune Ugovora o osnivanju Evropske unije (Mastrihtski ugovor) i Ugovora o osnivanju Evropske ekonomske zajednice (Rimski ugovor). Potpisan je u Lisabonu 13. decembra 2007., stupio na snagu 1. decembra 2009. godine, prvog dana mjeseca koji slijedi nakon deponovanja poslednje ratifikacije, kao što je to predviđeno članom 6.2 Ugovora. (Official Journal C 306, Vol. 50, 17. December 2007).

${ }^{29}$ Povelja o osnovnim pravima, međutim, nije inkorporisana u tekst Lisabonskog ugovora, već se članom 6.1 na nju upućuje i istovremeno izričito navodi da ona ima istu pravnu snagu kao i osnivački ugovori. Međutim, Ugovor se ne poziva na originalnu verziju Povelje, koju su države članice potpisale u Nici, već na njenu revidiranu verziju, potpisanu 12. decembra 2007. godine. Član 6.1 stav 1 Lisabonskog ugovora glasi: „The Union recognises the rights, freedoms and principles set out in the Charter of Fundamental Rights of the European Union of 7 December 2007, as adapted in Strasbourg, on 12 December 2007, which shall have the same legal value as the Treates".

${ }^{30}$ Vidi Evropski sud, Belgijski predmet o jezicima, presuda od 23. jula 1968, serija A, broj 6.
} 
Miodrag N. Simović, Milena Simović: Izborno zakonodavstvo u Bosni i Hercegovini u kontekstu prakse...

odnosu na član 14 Evropske konvencije i član 1 Protokola broj 12 uz Evropsku konvenciju ${ }^{31}$.

Pomenuti pristup podjednako je adekvatan kada se radi o primjeni člana II/4 Ustava $\mathrm{BiH}$ u vezi s članom 25b) Međunarodnog pakta. U skladu s ovim pristupom, da bi za različito postupanje postojalo objektivno i razumno opravdanje, potrebno je da se kumulativno ispune dva uslova - da je razlikovanje ustanovljeno radi ostvarivanja nekog legitimnog cilja i da postoji razuman odnos proporcionalnosti između sredstava koja su upotrijebljena i cilja koji se želi postići.

Član 25 Međunarodnog pakta svakom građaninu garantuje pravo da može da učestvuje u javnim poslovima, pravo da bira i da bude izabran, kao i pravo pristupa javnim službama. Za razliku od člana 3 Protokola broj 1 uz Evropsku konvenciju, pravo da bira i da bude izabran prema članu 25 Međunarodnog pakta nije ograničeno na izbore za zakonodavna tijela, nego se primjenjuje generalno na ona tijela čije članstvo u potpunosti ili djelimično zavisi od izbora. Međunarodni pakt od država potpisnica zahtijeva da donesu takve zakone i druge mjere koje su neophodne kako bi građani imali efektivnu mogućnost da uživaju u pravima koja garantuje ovaj međunarodni instrument. U svom Komentaru o članu 25b) Međunarodnog pakta (usvojen na 57. sjednici od 12. jula 1996. godine) Komitet za ljudska prava UN-a je, između ostalog, naveo da „bilo kakvi uslovi koji se primjenjuju na uživanje prava zaštićenih članom 25b), moraju biti zasnovani na objektivnim i opravdanim kriterijumima [...] uživanje ovih prava građana ne može biti ukinuto ili isključeno osim pod uslovima koji su ustanovljeni zakonom i koji su objektivni i razumni“. U daljnjem dijelu Komentara Komitet za ljudska prava UN-a ukazuje na moguća opravdana ograničenja aktivnog i pasivnog biračkog prava kao što su minimalne godine života i neprihvatljiva ograničenja kao što su imovinski uslovi, stepen obrazovanja, pismenost, pripadnost političkoj partiji itd. Uz to, postoje uslovi pod kojima bi države trebale da organizuju izbore bez bilo kakvih pritisaka, prisile ili drugih oblika prinude u odnosu na glasače.

Komitet za ljudska prava UN-a je posebno istakao da Međunarodni pakt ne nameće obavezu postojanja nekog određenog izbornog sistema, ali da uspostavljeni sistem u državi ugovornici mora da bude u skladu s pravima zaštićenim članom 25b) Međunarodnog pakta i da odražava izraženu slobodnu volju birača. U Komentaru je naglašeno da se ,princip jedan čovjek, jedan glas mora primjenjivati i da se i okviru izbornog sistema svake države ugovornice

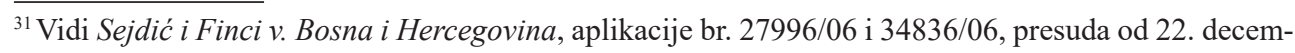
bra 2009. godine (Veliko vijeće). 
glas jednog birača treba biti jednak glasu drugog birača. Povlačenje granica biračkih jedinica i metoda dodjeljivanja glasova ne bi trebalo poremetiti raspored birača ili diskriminisati bilo koju grupu i ne bi trebalo isključiti ili nerazumno ograničiti pravo građana da svoje predstavnike slobodno izaberu (Mratović, 1971: 123-124).

\section{Praksa Evropskog suda za ljudska prava}

Evropski sud je u predmetu Sitaropoulos i Giakoumopoulos protiv Grčke $e^{32}$ razmatrao pitanje da li su javne vlasti obavezane članom 3 Protokola broj $1 \mathrm{uz}$ Evropsku konvenciju da uvedu sistem koji omogućava državljanima koji žive $\mathrm{u}$ inostranstvu da ostvaruju svoja prava glasa u inostranstvu. Evropski sud je istakao: „71. Opšte uzev, član 3 Protokola broj 1 ne propisuje državama ugovornicama da sprovode mjere koje omogućavaju iseljenicima da ostvaruju pravo glasa u svom mjestu stanovanja. Ipak, s obzirom na to da pretpostavka u demokratskoj državi mora biti u korist inkluzije ${ }^{33}$, takve su mjere u skladu s tom odredbom. Pitanje je, međutim, da li član 3 Protokola broj 1 ide toliko daleko da zahtijeva njihovo preduzimanje. Kako bi se odgovorilo na to pitanje, član 3 treba tumačiti oslanjanjem na relevantno međunarodno i uporedno pravo $^{34}$, kao i kao i na zakonodavstvo zemlje o kojoj je riječ‘،.

Prvo, u pogledu međunarodnog prava, Sud primjećuje da ni relevantni međunarodni i regionalni ugovori (kao što su Međunarodni pakt, Američka konvencija o ljudskim pravima i Afrička povelja o ljudskim pravima i pravima naroda), kao ni njihovo tumačenje od strane nadležnih međunarodnih tijela, ne daju osnov za zaključak da prava glasa lica koja su privremeno ili trajno odsutna iz države čiji su državljani - idu toliko daleko da zahtijevaju od države u pitanju da uspostavi mehanizme za njihovo ostvarivanje u inostranstvu. Istina je da su sa ciljem boljeg ostvarivanja prava glasa na parlamentarnim izborima, institucije Savjeta Evrope, između ostalog, pozvale države članice da omoguće svojim državljanima koji žive u inostranstvu da učestvuju u izbornom procesu u najvećoj mogućoj mjeri. Evropska komisija za demokratiju putem prava (Venecijanska komisija) je, pak, primijetila da je od osamdesetih godina 20. vijeka priznavanje eksternih biračkih prava postalo rasprostranjeno u Evropi. Premda je takođe preporučila da države članice

\footnotetext{
${ }^{32}$ Vidi Evropski sud, presuda od 15. marta 2012. godine, stav 70.

${ }^{33}$ Vidi Hirst v. the United Kingdom (no. 2) [GC], no. 74025/01, § 61, ECHR 2005-IX, 59.

${ }^{34}$ Vidi Yumak and Sadak v. Turkey [GC], no. 10226/03, § 111, ECHR 2008, 127 i Demir and Baykara v. Turkey [GC], no. 34503/97, §§ 76 and 85, ECHR 2008.
} 
Miodrag N. Simović, Milena Simović: Izborno zakonodavstvo u Bosni i Hercegovini u kontekstu prakse...

omoguće ostvarenje prava glasa iseljenika, Komisija nije smatrala da su one obavezne da to učine. Naprotiv, taj potez je vidjela kao mogućnost koju treba da razmotri zakonodavno tijelo u svakoj zemlji, a koje treba da ostvari ravnotežu između principa opšteg prava glasa, s jedne, i potrebe za bezbjednošću glasova i uređenju drugih praktičnih pitanja, s druge strane.

Pored toga, uporedno istraživanje zakonodavstva država članica Savjeta Evrope u ovoj oblasti pokazuje da iako velika većina njih omogućava svojim državljanima da glasaju u inostranstvu, neke to ne dozvoljavaju. Međutim, podrobnije razmatranje zakona onih država koje omogućavaju glasanje u inostranstvu - pokazuje da ne postoje ujednačeni mehanizmi za ostvarivanje prava glasa iseljenika, već da oni imaju raznovrsne oblike. Na kraju, u većini država članica koje dozvoljavaju glasanje u inostranstvu, lica koja žele da iskoriste ovu mogućnost moraju da se do određenog roka upišu u birački spisak kod vlasti svoje zemlje porijekla ili pri njenim diplomatskim ili konzularnim organima u inostranstvu. Ukratko, nijedan od više razmotrenih pravnih instrumenata ne daje osnov za zaključak da prema sadašnjem pravu države imaju obavezu da omoguće svojim državljanima koji žive u inostranstvu da ostvaruju svoje pravo glasa. Trenutno postoje veoma raznovrsni pristupi u pogledu mehanizama za ostvarivanje tog prava koje su uvele države članice Savjeta Evrope koje omogućavaju glasanje u inostranstvu.

Shodno citiranom stavu Evropskog suda, proizilazi da ni član 3 Protokola broj 1 uz Evropsku konvenciju, pa shodno tome ni član 25 Međunarodnog pakta, na koje su se pozvali podnosioci zahtjeva, ne nameću osnov za zaključak da države imaju obavezu da omoguće svojim državljanima koji žive u inostranstvu da ostvaruju svoje pravo glasa tamo gdje i žive. Također, navedenim odredbama ne nameće se određeni mehanizam za ostvarivanje prava glasa kada je ono priznato državljanima van zemlje. U tom smislu, i uspostavljanje mehanizma prema kojem je ostvarivanje prava glasa u inostranstvu, odnosno u mjestu gdje birač živi u inostranstvu uslovljeno, između ostalog, i upisom, do određenog roka, u birački spisak kod vlasti svoje zemlje porijekla ili pri njenim diplomatskim ili konzularnim organima u inostranstvu, a što je upravo i slučaj sa većinom zemalja koje svojim državljanima u inostranstvu dozvoljavaju pravo glasa - nije u suprotnosti sa pravom iz člana 3 Protokola broj 1 , te iz člana 25 Međunarodnog pakta.

Članom 3 Zakona o državljanstvu $\mathrm{BiH}^{35}$ određeno da svi državljani $\mathrm{BiH}$ uživaju ista ljudska prava i osnovne slobode kao što je to određeno Ustavom

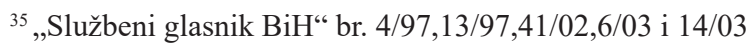


$\mathrm{BiH}$ i uživaju zaštitu ovih prava na čitavoj teritoriji $\mathrm{BiH}$, pod istim uslovima. Prema članu 1.4 Izbornog zakona, svim državljanima BiH garantuje se biračko pravo (da biraju i da budu izabrani) u skladu s odredbama ovog zakona, uz uslove koji se primjenjuju na sve državljane $\mathrm{BiH}$ - da imaju navršenih 18 godina i da su upisani u Centralni birački spisak u skladu s odredbama ovog zakona. Shodno navedenim odredbama, nesporno proizilazi da je biračko pravo priznato svim državljanima $\mathrm{BiH}$, bez obzira na to da li žive u inostranstvu ili u BiH ili da li su izbjeglice iz BiH. Ustavni sud je u svojoj dosadašnjoj praksi zauzeo stav da se radi o zakonom garantovanom pravu u odnosu na koje javne vlasti nikog ne smiju diskriminisati ${ }^{36}$.

Evropski sud je u predmetu Sejdić i Finci protiv Bosne i Hercegovine, tačka 41, odlučio većinom glasova da je prošlo previše vremena od kraja rata da bi Bosna i Hercegovina nastavila da opravdava posebnim potrebama, u drugoj polovini 2009. godine, diskriminatorske odredbe u Ustavu BiH koje se tiču zastupanja Ostalih u Domu naroda Parlamentarne skupštine BiH i u Predsjedništvu BiH. Dok prihvata da ,prema Konvenciji ne postoji zahtjev da se u potpunosti odustane od instrumenata podjele vlasti koji su svojstveni Bosni i Hercegovini i da još nije došlo vrijeme za politički sistem koji bi bio jednostavan odraz vladavine većine“, Evropski sud je zapazio da „postoje instrumenti podjele vlasti koji automatski ne vode ka potpunom isključivanju predstavnika drugih zajednica“". U vezi sa ovim, Evropski sud podsjeća da mogućnost alternativnih sredstava kojima se postiže isti cilj - čini važan faktor u ovoj sferi ${ }^{37}$. Dalje, sud je smatrao važnim što je 2002. godine Bosna i Hercegovina pristupila Evropskoj konvenciji bez rezervi i samim tim se obavezala da će ispunjavati norme propisane Konvencijom (tačka 49).

U presudi Evropskog suda u predmetu Sejdić $i$ Finci u tački 44 je navedeno: „U ovakvom kontekstu, gdje se razlika u tretmanu zasniva na rasi i etničkom porijeklu, pojam objektivnog i razumnog opravdanja mora da se tumači što je moguće preciznije ... Sud takođe smatra da ni jedna vrsta različitog postupanja, koja se isključivo ili u kritičnom obimu zasniva na etničkom porijeklu pojedinca, ne može objektivno da se opravda u savremenom demokratskom društvu koje je izgrađeno na principima pluralizma i poštovanja različitih kultura ... S obzirom na navedeno, član 14 ne zabranjuje stranama ugovornicama da različito tretiraju grupe kako bi ispravile 'činjenične nejednakosti’ između njih. I zaista, u određenim situacijama ne pokušati da se

\footnotetext{
${ }^{36}$ Vidi Ustavni sud, Odluka o dopustivosti i meritumu, broj U-14/12 od 26. marta 2015. godine, tačka 62, dostupna na www.ustavnisud.ba.

${ }^{37}$ Vidi Glor protiv Švajcarske, br. 13444/04, stav 94, 30. april 2009. godine i tačku 48 Sejdić i Finci.
} 
isprave nejednakosti kroz različit tretman, bez objektivnog i razumnog opravdanja, može da dovede do kršenja tog člana“"38.

Takođe, u tački 48 predmetne presude je navedeno: „Pored toga, iako se Sud slaže sa Vladom da nijedna odredba Konvencije ne traži potpuno napuštanje mehanizama podjele vlasti koji su svojstveni Bosni i Hercegovini i da možda još uvijek nije sazrelo vrijeme za politički sistem koji bi bio samo odraz principa vladavine većine, mišljenja Venecijanske komisije (vidjeti tačku 22 u tekstu) jasno pokazuju da postoje takvi mehanizmi podjele vlasti koji ne vode automatski do potpunog isključenja predstavnika ostalih zajednica. U vezi sa ovim, Sud je podsjetio da mogućnost da se drugačijim sredstvima postigne isti cilj - predstavlja važan faktor u ovoj oblasti“‘39.

Izgleda da ovo ukazuje na to da, budući da se radi o pitanju iz domena evropskog prava ljudskih prava, sada ne postoji opravdanje prema članu II/4 Ustava $\mathrm{BiH}$ da se zadrže osporene odredbe. Međutim, Ustavni sud se nije smatrao obaveznim da zauzme takav pristup u predmetu broj U-9/09 (Izborni zakon Bosne i Hercegovine i Statut Grada Mostara) iz dva razloga. Kao prvo, presuda Evropskog suda, kao i sve presude koje se tiču opravdanja za moguće diskriminatorske postupke ili pravila, fokusira se na konkretne činjenice i pitanja s kojima se susreće. Predmet Sejdić $i$ Finci odnosi se na rješenja koja u potpunosti isključuju mogućnost kandidovanja svih lica koja ne pripadaju jednom od tri konstitutivna naroda na izborima za Dom naroda Parlamentarne skupštine $\mathrm{BiH}$ i za Predsjedništvo $\mathrm{BiH}$. Za razliku od spomenutog, odredbe koje se osporavaju u predmetu U-9/09 posebno štite pravo Ostalih da budu zastupljeni u Gradskom vijeću Mostara. Kao drugo, dok je Evropski sud krajnji autoritet u pitanju tumačenja i primjene Evropske konvencije, Ustavni sud je krajnji autoritet u pitanju tumačenja i primjene Ustava $\mathrm{BiH}$, uključujući i član II/4. Dok su opšti principi koji se primjenjuju na pitanja diskriminacije isti i prema članu II/4 i prema Evropskoj konvenciji, Ustavni sud je taj koji odlučuje da li postoji objektivno i razumno opravdanje u svakom pojedinačnom predmetu u smislu člana II/4.

U tom kontekstu, Ustavni sud mora da uzme u obzir svoje sopstveno znanje i razumijevanje situacije u Bosni i Hercegovini. Budući da je mnogo bliži i upućeniji u društvene i političke uslove života u Bosni i Hercegovini u današnjem vremenu nego što je to slučaj sa Evropskim sudom, Ustavni sud je u boljoj poziciji od Evropskog suda da procijeni da li su opravdani postupci

\footnotetext{
${ }^{38}$ Slučaj koji se odnosi određene aspekte zakona o korišćenju jezika u obrazovanju u Belgiji, tačka $10 \mathrm{i}$ Thlimmenos protiv Grčke [GC], broj 34369/97, tačka 44, ECHR 2000-IV.

${ }^{39}$ Vidjeti Glor protiv Švajcarske, broj 13444/04, tačka 94, 30. april 2009. godine.
} 
ili pravila koji, ako nisu opravdani, dovode do neustavne diskriminacije. U vezi s tim, Ustavni sud zapaža da je Venecijanska komisija u svom podnesku kao amicus curiae u ovom predmetu prihvatila da bi poseban položaj Mostara mogao da pruži objektivno i racionalno opravdanje za njegov jedinstven izborni aranžman, uz konstataciju da bi Ustavni sud prilikom ocjenjivanja mogućih opravdanja trebao da uzme u obzir sve izmjene u situaciji koje su se desile tokom zadnjih 15 godina. Ustavni sud se slaže da je ovo odgovarajući način da se pristupi ovom pitanju.

U presudi u predmetu Baralija protiv Bosne i Hercegovine ${ }^{40}$ Evropski sud je jednoglasno odlučio da je došlo do povrede člana 1 Protokola broj 12 (opšta zabrana diskriminacije) uz Evropsku konvenciju. Predmetni slučaj se ticao pravne praznine koja je onemogućila podnositeljiki predstavke, lokalnoj političarki koja živi u Mostaru, da glasa i bude birana na lokalnim izborima. Sud je utvrdio da je pravna praznina nastala propustom vlasti da izvrše odluku Ustavnog suda iz 2010. godine, koja se ticala odredaba koje su regulisale lokalne izbore u Mostaru, te nalagala vlastima da usklade te odredbe sa Ustavom BiH. To je za posljedicu imalo situaciju gdje su posljednji lokalni izbori u Mostaru održani 2008. godine, te gdje je gradom upravljao gradonačelnik koji od 2012. godine nije imao potrebni demokratski legitimitet. Takva situacija nije bila u skladu sa načelom vladavine prava. Evropski sud stoga nije mogao prihvatiti argument Vlade da je višegodišnje kašnjenje u izvršenju odluke bilo opravdano potrebom da se dođe do dugoročnog i održivog rješenja za podjelu vlasti, te da se očuva mir i omogući dijalog između različitih etničkih grupa u Mostaru. Tužena država je stoga prekršila svoju obavezu da preduzme mjere da zaštiti podnositeljku predstavke od diskriminatornog postupanja po osnovu njenog mjesta prebivališta i da održi demokratske izbore u Mostaru. Sud je takođe utvrdio (jednoglasno), na osnovu člana 46 (obaveznost i izvršenje presuda), da tužena država mora izmijeniti relevantno zakonodavstvo najkasnije u roku od šest mjeseci nakon što ova presuda postane konačna.

Evropski sud je odlučio primijeniti standardno tumačenje koje je razvio u svojoj praksi o diskriminaciji, naime da je bilo kakva razlika u postupanju

\footnotetext{
${ }^{40}$ Predmet broj 30100/18, od 29. oktobra 2019. godine. Podnositeljica predstavke, Irma Baralija, drŽavljanka je Bosne i Hercegovine, rođena 1984. godine. Živi u Mostaru, predsjednica je Gradskog odbora političke partije Naša stranka u Mostaru. U novembru 2010. godine Ustavni sud je proglasio neustavnim određene odredbe Izbornog zakona koje su regulisale lokalne izbore u Mostaru. Utvrdio je da način na koji su organizovane izborne jedinice i broj gradskih vijećnika iz svake od tih jedinica - nisu bili u skladu sa načelom jednakog prava glasa. Dao je relevantnim vlastima šest mjeseci da usklade te odredbe sa Ustavom BiH. Ta odluka, međutim, još uvijek nije bila izvršena.
} 
Miodrag N. Simović, Milena Simović: Izborno zakonodavstvo u Bosni i Hercegovini u kontekstu prakse...

među osobama u istim ili relativno sličnim situacijama diskriminatorna ako nema „objektivno i razumno opravdanje“. Nije bilo sporno da je podnositeljka predstavke imala pravo da glasa i bude birana na izborima i da je, kao osoba sa prebivalištem u Mostaru, bila u istoj ili relevantno sličnoj situaciji sa onima koji su prebivalište imali drugdje u Bosni i Hercegovini. Kako je razlika u postupanju u ovom slučaju bila temeljena na ličnom statusu u smislu prakse Suda, naime isto zakonodavstvo je primijenjeno različito zavisno od prebivališta osobe, Sud je našao da je podnositeljka predstavke uživala zaštitu člana 1 Protokola broj 12. Sud je razmatrao Vladin argument da je kašnjenje u izvršenju odluke Ustavnog suda bilo opravdano potrebom da se dođe do dugoročnog i održivog rješenja za podjelu vlasti, te da se očuva mir i omogući dijalog između različitih etničkih grupa u Mostaru. Međutim, Sud nije mogao prihvatiti da su poteškoće u dolasku do političkog dogovora $\mathrm{s}$ tim u vezi bile dovoljno, objektivno i razumno opravdanje za situaciju gdje su posljednji lokalni izbori u Mostaru održani 2008. godine i gdje je gradom upravljao gradonačelnik koji je od 2012. godine bio u „tehničkom mandatu“, te stoga nije imao potrebni demokratski legitimitet. Takva situacija nije bila u skladu sa načelima „stvarne političke demokratije“ i „vladavine prava“ na koje Evropska konvencija upućuje u svojoj preambuli. Dakle, Sud je odlučio da je tužena država prekršila svoju obavezu da preduzme mjere da zaštiti podnositeljku predstavke od diskriminatornog postupanja po osnovu njenog mjesta prebivališta i da održi demokratske izbore u Mostaru. Stoga je došlo do povrede člana 1 Protokola broj 12 uz Evropsku konvenciju.

Imajući u vidu veliki broj potencijalnih podnositelja predstavke i hitnu potrebu da se okonča trenutna situacija, Sud je zaključio da tužena država mora izmijeniti Izborni zakon najkasnije u roku od šest mjeseci od kad ova presuda postane konačna - da bi omogućila održavanje lokalnih izbora u Mostaru. Ukoliko tužena država propusti to učiniti, Sud je konstatovao da Ustavni sud ima ovlaštenje da sam uspostavi privremeno rješenje.

Sud je odlučio da je nalaženje povrede samo po sebi dovoljna satisfakcija za neimovinsku štetu koju je pretrpjela podnositeljka predstavke. Sud je, isto tako, odlučio da Bosna i Hercegovina mora podnositeljki predstavke platiti 5.000 eura na ime advokatskih troškova.

U predmetu Mugemangango v. Belgium ${ }^{41}$ slučaj se odnosio na postizborni spor vezan za izbore koji su održani 25. maja 2014. Pred Evropskim sudom

\footnotetext{
${ }^{41}$ Application no. 310/15, 10. juli 2020. godine, presuda Velikog vijeća, povreda člana 3 Protokola broj 1 uz Evropsku konvenciju (pravo na slobodne izbore) i povreda člana 13 ove konvencije.
} 
aplikant se žalio na postupak koji je proveo Parlament Valonije nakon što je osporio izborne rezultate. Tvrdio je da je Parlament Valonije, koji je bio jedino tijelo koje je prema domaćem pravu imalo nadležnost da odlučuje o njegovoj žalbi, bio i sudija i stranka u postupku ispitivanja njegove žalbe.

Evropski sud je utvrdio da je aplikantovu pritužbu ispitalo tijelo koje nije pružilo potrebna jemstva za svoju nepristranost i čija diskrecija nije bila dovoljno precizno ograničene odredbama domaćeg prava. Zaštitne mjere koje su aplikantu pružene tokom postupka - takođe su bile nedovoljne, jer su uvedene na diskrecionoj osnovi. O njegovim pritužbama nije odlučeno u postupku koji je imao odgovarajuće i dovoljne zaštitne mjere za sprečavanje samovolje i osiguranje učinkovitog ispitivanja. Sud je takođe utvrdio da u odsustvu ovih zaštitnih mjera, ovaj pravni lijek nije bio efektivan u smislu člana 13 Evropske konvencije.

\section{Apstraktna nadležnost Ustavnog suda}

Odluka o meritumu broj U- 7/05 od 2. decembra 2005. godine (Statut Grada Istočno Sarajevo ${ }^{42}$ i Statut Grada Banja Luka ${ }^{43}$ )

U ovoj odluci Ustavni sud je odbio zahtjev člana Predsjedništva BiH i utvrdio da su Statut Grada Istočno Sarajevo i Statut Grada Banja Luka u skladu sa Ustavom BiH. Nepropisivanjem odredaba o garantovanoj minimalnoj zastupljenosti konstitutivnih naroda, Bošnjaci i Hrvati nisu diskriminisani u uživanju svojih političkih prava, s obzirom na to da im osporenim statutima nije onemogućena jednakost u uživanju političkih prava iz člana 5 stav 1c) Međunarodne konvencije o ukidanju svih oblika rasne diskriminacije. Naime, Bošnjaci i Hrvati, kao i Srbi, pod jednakim uslovima imaju pravo glasa i kandidature, te pravo učešća na izborima, od čijeg ishoda kasnije zavisi učestvovanje u vlasti. Nepropisivanje odredaba o garantovanoj minimalnoj zastupljenosti može potencijalno dovesti do toga da bilo koji od konstitutivnih naroda bude u apsolutnoj većini na gradskom nivou vlasti, ali to bi uvijek zavisilo od ishoda izbornih rezultata.

Ustavni sud je u svojoj praksi već elaborisao pitanje svoje nadležnosti iz člana VI/3a) Ustava BiH, u sličnoj situaciji kada je predmet ocjene bio Statut Grada Sarajeva i zaključio da je "kao institucija koja podržava Ustav BiH, nadležan da ispituje ustavnost svih akata, bez obzira na donosioca, ako je

\footnotetext{
${ }^{42}$ „Službene novine Grada Istočno Sarajevo” br. 10/00 i 1/02.

${ }^{43}$ „Službeni glasnik Grada Banja Luka” broj 4/00.
} 
Miodrag N. Simović, Milena Simović: Izborno zakonodavstvo u Bosni i Hercegovini u kontekstu prakse...

pitanje pokrenuto shodno jednoj od nadležnosti Ustavnog suda iz člana VI/3 Ustava BiH. U skladu sa argumentacijom o ljudskim pravima, Ustavni sud je mišljenja da, kad god je to moguće, mora da interpretira svoju jurisdikciju tako da dozvoli najširu mogućnost otklanjanja posljedica kršenja tih prava. U konkretnom slučaju, zahtjev za ocjenu ustavnosti se upravo odnosi na pitanja koja proizilaze iz Ustava $\mathrm{BiH}$ i međunarodnih sporazuma kojima se garantuje zaštita ljudskih prava i tiče se ostvarivanja ljudskih prava i ustavnih principa, kao što je princip konstitutivnosti naroda i pravo na zabranu diskriminacije ${ }^{\text {“44 }}$.

Rukovodeći se principima iz navedene odluke, Ustavni sud se i u konkretnom slučaju smatra nadležnim za ocjenu ustavnosti. I ovdje se radi o zahtjevu za ocjenu ustavnosti koji se odnosi na pitanja koja proizilaze iz Ustava $\mathrm{BiH}$ i međunarodnih sporazuma o zaštiti ljudskih prava, odnosno zaštite ljudskih prava i ostvarenje principa konstitutivnosti i prava na zabranu diskriminacije.

Podnosilac zahtjeva smatra da je nepropisivanjem odredbi u osporenim statutima, kojim bi se obezbijedila minimalna zastupljenost konstitutivnih naroda u Skupštini Grada Banja Luka i Skupštini Grada Istočno Sarajevo, povrijeđen princip konstitutivnosti naroda. Podnosilac zahtjeva se, s tim u vezi, pozvao na Odluku Ustavnog suda broj U-4/05 u kojoj je Ustavni sud odlučivao o usklađenosti Statuta Grada Sarajeva sa principom konstitutivnosti naroda u Bosni i Hercegovini.

U svojoj odluci broj U-4/05, na koju se poziva podnosilac zahtjeva, Ustavni sud je konstatovao da je narušen ustavni princip konstitutivnosti naroda na cijeloj teritoriji Bosne i Hercegovine u slučaju kada jednom konstitutivnom narodu nije bilo garantovano učešće u predstavničkom organu, koje je bilo garantovano za druga dva konstitutivna naroda ${ }^{45}$. Ustavni sud je utvrdio da je neustavna odredba Statuta Grada Sarajeva kojom je garantovan određeni procenat minimalne zastupljenosti bez obzira na izborne rezultate $u$ korist bošnjačkog i hrvatskog naroda i grupe Ostalih, dok iste garancije nisu postojale za srpski narod. Uz to, Ustavni sud je utvrdio i da osporena odredba Statuta Grada Sarajeva krši pravo Srba na zabranu diskriminacije iz člana II/4 Ustava BiH u odnosu na politička prava iz člana 5 stav 1 tačka c) Konvencije o eliminisanju svih oblika rasne diskriminacije iz 1965. godine.

Ustavni sud smatra da se ovdje ne radi o takvom slučaju. Naime, osporeni statuti ne sadrže niti jednu odredbu kojom se nekom od konstitutivnih naroda omogućava privilegovan status. Takođe, Ustavni sud uočava da ne

\footnotetext{
${ }^{44}$ Vidi odluku Ustavnog suda, broj U-4/05 od 22. aprila 2005. godine, st. 14-17.

${ }^{45}$ Vidi Odluku Ustavnog suda, broj U-4/05 od 22. aprila 2005. godine, objavljenu u „Službenom glasniku BiH“" broj 32/05.
} 
postoji odredba u Ustavu BiH ili ustavima entiteta, koja nameće obavezu da u statutima gradova ili opština postoji odredba o minimalnoj zastupljenosti konstitutivnih naroda - bez obzira na izborne rezultate. Takva odredba nije sadržana ni u Izbornom zakonu BiH, koji sadrži isključivo odredbe kojima se predviđa zabrana diskriminacije. S obzirom na nepostojanje takve izričite odredbe, Ustavni sud smatra da bi bilo pogrešno da Ustavni sud zakonodavnim organima nameće obavezu donošenja novih statuta gradova i opština $u$ kojima bi se ugradila odredba o minimalnoj zastupljenosti konstitutivnih naroda - bez obzira na izborne rezultate.

Odluka o dopustivosti i meritumu broj U-9/09 (Izborni zakon Bosne i Hercegovine $^{46}$ i Statut Grada Mostara ${ }^{47}$ )

Ustavni sud je utvrdio da:

- član 19.4 stav 2 Izbornog zakona BiH i član 17 stav 1 Statuta Grada Mostara u dijelu u kojem glasi: „U svakom gradskom području se biraju po tri (3) vijećnika“ nisu u skladu s članom 25 Međunarodnog pakta koji je sastavni dio Ustava $\mathrm{BiH}$;

- odredbe člana 19.2 st. 1 i 3, te člana 19.4 st. 2-8. Izbornog zakona BiH i člana 17 stav 1 Statuta Grada Mostara u dijelu koji glasi: „U svakom gradskom području se biraju po tri (3) vijećnika" nisu u skladu s članom II/4 Ustava $\mathrm{BiH}$ u vezi s članom 25 Međunarodnog pakta;

- član 7 st. 1 i 3, član 15 stav 2, član 17 stav 1 i član 38 stav 1 Statuta Grada Mostara nisu u skladu s članom II/4 Ustava BiH u vezi s članom 25b) Međunarodnog pakta;

- odredbe člana 19.4 st. 1 i 9, te člana 19.7 Izbornog zakona BiH, odredba člana VIC stav 7 Amandmana CI na Ustav Federacije BiH, preostale odredbe čl. 7 i 15, član 16, preostale odredbe čl. 17 i 38, te čl. 44 i 45 Statuta Grada Mostara u skladu su s članom II/4 Ustava BiH u vezi s članom 25 Međunarodnog pakta.

Ustavni sud zaključuje da odredbe člana 19.4 st. 1 i 9 Izbornog zakona i člana 16 Statuta, kojima su propisani donji i gornji limit zastupljenosti konstitutivnih naroda u Gradskom vijeću, ne diskriminišu hrvatski narod u ostvarivanju njegovih prava iz člana II/4 Ustava $\mathrm{BiH}$ u vezi s članom 25b) Međunarodnog pakta. S druge strane, Ustavni sud usvaja zahtjev podnosioca

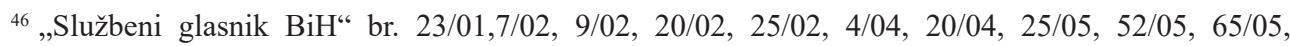
77/05,11/06, 24/06, 32/07, 33/08 i 37/08.

${ }^{47}$ „Gradski službeni glasnik Grada Mostara“ broj 4/04.
} 
Miodrag N. Simović, Milena Simović: Izborno zakonodavstvo u Bosni i Hercegovini u kontekstu prakse...

zahtjeva u pogledu: (a) navoda da su odredbama člana 19.2 st. 1 i 3, člana 19.4 stav 1 Izbornog zakona, zbog kojeg različit broj birača u izbornim jedinicama koji se zasniva na bivšim gradskim područjima u Mostaru, krši član 25b) Međunarodnog pakta, te (b) navod da odredbe člana 19.2. stav 1 i člana 19.4 čl. 2 do 8 onemogućavaju biračima iz Centralne zone Grada Mostara da biraju vijećnike koji bi ih zastupali uz vijećnike koji zastupaju gradsko izborno područje za cijeli Grad Mostar - krše član II/4 Ustava BiH u vezi s članom 25b) Međunarodnog pakta.

Ustavni sud odlučuje da član 7 st. 1 i 3, član 15 stav 2, član 17 stav 1 i član 38 stav 1 Statuta, koji onemogućava biračima u Centralnoj zoni Grada Mostara da biraju vijećnike koji bi ih zastupali uz vijećnike koji zastupaju gradsko izborno područje za cijeli Grad Mostar, krše član II/4 Ustava BiH u vezi s članom 25b) Međunarodnog pakta. Ustavni sud odlaže dalje postupanje po ovom dijelu zahtjeva sine die do donošenja izmjena Izbornog zakona u skladu s ovom odlukom. Ustavni sud nalaže Gradskom vijeću Grada Mostara da izvijesti Ustavni sud u roku od tri mjeseca od dana objave izmjena koje Parlamentarna skupština BiH izvrši u Izbornom zakonu BiH u „Službenom glasniku BiH“" o koracima preduzetim kako bi se Statut Grada Mostara uskladio sa Ustavom BiH.

Na kraju, Ustavni suda smatra da su odredbe člana 19.7 Izbornog zakona, člana VIC. stav 7 Amandmana na Ustav Federacije BiH i čl. 44 i 45 Statuta, prema kojima građani Grada Mostara biraju gradonačelnika na drugačiji način u odnosu na građane Grada Banja Luke, u skladu sa pravima građana Grada Mostara zagarantovanim prema članu 25b) Međunarodnog pakta, te da ne diskriminišu građane Grada Mostara u uživanju navedenog prava protivno članu II/4 Ustava BiH.

Ustavni sud smatra da nije neophodno da odluči da li član 19.4 stav 2 Izbornog zakona i član 17 stav 1 Statuta krše neki temeljni princip Izbornog zakona ili da ispita osporene odredbe čl. 19.1, 19.2 stav 2, 19.3, 19.5 i 19.6 Izbornog zakona i odredbe člana VIC stav 4 Amandmana CI na Ustav Federacije $\mathrm{BiH}$, pozivanjem na nepotkrijepljene navode podnosioca zahtjeva koji se odnose na Međunarodnu konvenciju o ukidanju svih oblika rasne diskriminacije.

Venecijanska komisija je navela da odredbe čl. 19.4 i 19.6 Izbornog zakona, koje regulišu izbor Gradskog vijeća, odstupaju od principa jednake težine svakog glasa jer uspostavljaju minimalni i maksimalni prag zastupljenosti tri konstitutivna naroda i Ostalih. Venecijanska komisija je navela da te odredbe garantuju zastupljenost svih konstitutivnih naroda i Ostalih, te sprječavaju 
dominaciju jednog konstitutivnog naroda ili Ostalih u Gradskom vijeću. U vezi s tim, Venecijanska komisija je navela da je prilikom ocjenjivanja odnosnih odredbi odlučujuće da li ograničenje principa jednake težine glasa može da se smatra razumnim i zasnovanim na objektivnim kriterijumima prema utvrđenim principima Evropskog suda i Komiteta za ljudska prava UN-a. Venecijanska komisija je istakla da je u svom mišljenju o Izbornom zakonu BiH iz 2001. godine navela „da je raspodjela radnih mjesta u državnim organima između konstitutivnih naroda bila centralni elemenat Dejtonskog sporazuma koji je omogućio mir u Bosni i Hercegovini, te da je u tom smislu teško opovrgnuti zakonitost normi koje bi mogle biti problematične u kontekstu nediskriminacije, ali neophodne da se postigne mir i stabilnost". Venecijanka komisija je istakla „da, iako se situacija u Bosni i Hercegovini razvijala u pozitivnom smislu, i dalje ostaju okolnosti koje zahtijevaju politički sistem koji nije prosti odraz pravila većine, već koji garantuje raspodjelu vlasti i pozicija među nacionalnim skupinama, te da pokušaji da se izrade izborna pravila koja omogućavaju odgovarajuću zastupljenost za razne skupine i dalje ostaju zakoniti“.

Dalje, Venecijanska komisija je ukazala na Odluku Ustavnog suda broj U-4/05, koja se tiče izbornog sistema Grada Sarajeva, u kojoj je Ustavni sud naveo „da je neophodno da sva tri konstitutivna naroda dobiju minimum garancija za učešće u Gradskom vijeću bez obzira na izborne rezultate, budući da je to jedini način da se ispoštuje princip konstitutivnosti naroda na cijeloj teritoriji Bosne i Hercegovine“. Takođe, Venecijanska komisija je ukazala na treću Djelimičnu odluku Ustavnog suda u predmetu broj U-5/98 u kojoj je Ustavni sud naveo „da dosljedna primjena demokratskog principa - jedan birač jedan glas, u postojećim političkim prilikama u Bosni i Hercegovini, nosi rizik stvaranja jednonacionalne vlasti izabrane u područjima u kojima je jedan konstitutivan narod u većini“" Imajući u vidu navedeno, Venecijanska komisija je navela da, prema opštim prilikama u Bosni i Hercegovini i specifičnim okolnostima u Mostaru, garantovanje zastupljenosti u izabranim tijelima svih konstitutivnih naroda i Ostalih, kao i sprječavanje bilo koje grupe da dominira u takvim tijelima, ostaje zakonit cilj, iako bi razvoj trebao da se kreće u smislu sistema koji daje veću težinu izbornim rezultatima. Pri tome, Venecijanska komisija je istakla da su slična rješenja usvojena za Grad Sarajevo (kao što slijedi iz Odluke U-4/05), kao i u drugim evropskim gradovima sa sličnim kontekstima multinacionalnog ili multijezičkog sastava (npr. u Belgiji). Prema mišljenju Venecijanske komisije, odstupanja od principa jednake težine svakog glasa proporcionalna su zakonitom cilju kojem se teži i ispunjavaju kriterijum razumnosti i objektivnosti kako se to zahtijeva 
Protokolom broj 12 uz Evropsku konvenciju, članom 25 Međunarodnog pakta i Opštim komentarom Komiteta za ljudska prava UN-a. Takođe, Venecijanska komisija je navela da to važi i za odredbe o organizaciji i sastavu komisija Gradskog vijeća koji slijede isti kriterijum.

U pogledu bivše Centralne zone, Venecijanska komisija je navela da građani bivše Centralne zone, za razliku od građana koji žive u bilo kojemm od šest gradskih područja, glasaju samo za 17 vijećnika koji se biraju u izbornoj jedinici na nivou Grada, ali ne i za 18 vijećnika koji se biraju na nivou gradskih područja kao izbornih jedinica. Venecijanska komisija je istakla da iz navedenog proizilazi da su biračka prava građana bivše Centralne zone manja od onih koja imaju ostali građani Mostara, te da je osnova za takvo drugačije postupanje čisto geografske prirode. U vezi s tim, Venecijanska komisija je navela da nije obaviještena o bilo kakvim posebnim razlozima za takvo postupanje, tako da u nedostatku razumnog i objektivnog opravdanja - ta razlika u postupanju djeluje diskriminatorski i predstavlja kršenje Protokola broj 12 uz Evropsku konvenciju.

Također, Venecijanska komisija je navela da Gradsko vijeće ima neposrednu i veliku moć u odnosu na Centralnu zonu u oblastima (raspodjela prihoda ostvarenih iz naknada po osnovu dodjele zemljišta u sklopu bivše Centralne zone) koja su u gradskim područjima u nadležnosti komisija Gradskog vijeća. Venecijanska komisija smatra da su na taj način građani bivše Centralne zone na diskriminišući način lišeni prava da samostalno i u svom interesu regulišu i upravljaju dijelom javnih pitanja, a da za to ne postoji nikakvo posebno i objektivno opravdanje, te da je stoga došlo do kršenja Protokola broj $12 \mathrm{uz}$ Evropsku konvenciju.

U pogledu izbora gradonačelnika, Venecijanska komisija je navela da se ni Ustav $\mathrm{BiH}$, niti međunarodni instrumenti na koje se podnosilac zahtjeva poziva, ne bave izborom gradonačelnika, ali da pružaju mogućnost neposrednog i posrednog izbora. Venecijanska komisija je navela da je posredni izbor usmjeren ka nacionalnom pomirenju koje je mnogo teže postići u kontekstu neposrednih izbora, da to predstavlja legitiman cilj, te da su osnove biračkog prava o kom je riječ očuvane. Shodno mišljenju Venecijanske komisije, u konkretnom slučaju postoji razumno i objektivno opravdanje za drugačije postupanje pri izboru gradonačelnika.

Način biranja gradonačelnika spada u djelokrug člana 25b) Međunarodnog pakta Međutim, taj član ne zahtijeva niti isključuje bilo koji posebni način biranja gradonačelnika. Nije neobično da se koriste različiti načini biranja u jednoj istoj državi - zavisno od okolnosti koje prevladavaju u određenim 
gradovima. Naprimjer, u Engleskoj i Velsu zakon dozvoljava da glasači u gradu neposredno biraju gradonačelnika ili da ga posredno biraju izabrani vijećnici; neki gradonačelnici se biraju neposredno, mada se većina bira posredno. Shodno mišljenju Ustavnog suda, pitanje koje se postavlja u svakom slučaju iz člana 25b) jeste da li je odabir načina izbora gradonačelnika proizvoljan, imajući u vidu da član 25b) prihvata da narod može da učestvuje u javnom životu bilo neposredno ili posredno preko svojih slobodno izabranih predstavnika. Kao što je slučaj s Gradom Mostarom, Ustavni sud prihvata da su vijećnici izabrani slobodnom voljom i da principi demokratije koja podupiru član 25 - u cijelosti dozvoljavaju da gradonačelnika biraju vijećnici prije nego da ga neposredno biraju glasači.

\section{Odluka o dopustivosti i meritumu, broj U-13/09}

(Izborni zakon Bosne i Hercegovine)

Član 9.1 st. 2 i 3, član 10.1 stav 3 i član 11.1 stav 2 Izbornog zakona $\mathrm{BiH}$ u skladu su sa alinejama 3, 8 i 9 Preambule Ustava BiH i članom I/2 Ustava BiH. Ustavni sud smatra da odredbe člana 9.1 st. 2 i 3, člana 10.1 stav 3 i člana 11.1 stav 2 Izbornog zakona nisu u nesaglasnosti sa alinejama 3, 8 i 9 Preambule Ustava $\mathrm{BiH}$ i članom $\mathrm{I} / 2$ Ustava $\mathrm{BiH}$ zato što nisu propisale mehanizme kojim bi se osigurala proporcionalna zastupljenost konstitutivnih naroda $\mathrm{BiH}$, prema popisu stanovništva iz 1991. godine, prilikom neposrednog biranja od samih građana - birača, članova Predstavničkog doma BiH, Predstavničkog doma Federacije BiH i Narodne skupštine Republike Srpske.

Ustavni sud ističe da je podnosilac zahtjeva zatražio ocjenu ustavnosti osporenih odredbi Izbornog zakona u odnosu na ustavne principe sadržane $u$ alinejama 3, 8 i 9 Preambule Ustava $\mathrm{BiH}$. U vezi s tim, Ustavni sud podsjeća da je u spomenutoj Odluci broj U-5/98 zauzeo stav da „odredbe Preambule pružaju pravnu osnovu za preispitivanje svih normativnih akata nižeg reda $\mathrm{u}$ odnosu na Ustav $\mathrm{BiH}$, dok god spomenuta preambula sadrži ustavne principe koji [...], opisuju sfere nadležnosti, doseg prava i obaveza ili uloge političkih institucija. Odredbe Preambule onda nisu samo opisne, već im je takođe data moćna normativna snaga, te one predstavljaju valjan standard za sudsku kontrolu Ustavnog suda“448. Imajući u vidu već zauzeti stav, Ustavni sud je ispitao ustavnost osporenog zakona u odnosu na navedene ustavne principe Preambule i član I/2 Ustava $\mathrm{BiH}$.

\footnotetext{
${ }^{48} \mathrm{U}-5 / 98$ III, tačka 26.
} 
Miodrag N. Simović, Milena Simović: Izborno zakonodavstvo u Bosni i Hercegovini u kontekstu prakse...

Ustavni sud zapaža da osporeni članovi, niti Izborni zakon u cjelini, ne sadrže niti jednu odredbu kojom se nekom od konstitutivnih naroda omogućava privilegovan status. Takođe, Ustavni sud uočava da ne postoji odredba $u$ Ustavu BiH koja nameće zakonodavcu obavezu da u Izbornom zakonu postoji odredba o mehanizmima za osiguranje proporcionalne zastupljenosti konstitutivnih naroda bez obzira na izborne rezultate. U odnosu na zahtjev podnosioca zahtjeva da se ocijeni ustavnost osporenih članova Izbornog zakona jer ne sadrže odredbe koje bi, prema mišljenju podnosioca zahtjeva, morali sadržavati, Ustavni sud ističe da ocjena ustavnosti i ne može da se odnosi na nešto što zakonodavac nije propisao.

Odluka o dopustivosti i meritumu, broj U-4/12 (Zakon o izmjenama i dopunama Izbornog zakona Republike Srpske)

Odredbe člana 4 stav 1 tačka 1 i člana 6 st. 1 i 3 Zakona o izmjenama i dopunama Izbornog zakona Republike Srpske ${ }^{49}$ nisu u skladu sa čl. I/2 i III/3b) Ustava BiH. Odredbe člana 3 st. 2 i 4 i člana 11 Zakona o izmjenama i dopunama Izbornog zakona Republike Srpske u skladu sa čl. I/2 i III/3b) Ustava BiH.

Ustavni sud zaključuje da odredbe člana 4 stav 1 tačka 1 i člana 6 st. 1 i 3 Zakona o izmjenama i dopunama Izbornog zakona Republike Srpske nisu u skladu s čl. I/2 i III/3b) Ustava $\mathrm{BiH}$, zato što se navedenim odredbama krši ustavni princip da su entiteti i druge administrativne jedinice u Bosni i Hercegovini dužni da se pridržavaju, između ostalog, i ,odluka institucija Bosne i Hercegovine“, u konkretnom slučaju principa iz odgovarajućih odredaba Izbornog zakona $\mathrm{BiH}$, čime se krši i princip vladavine prava iz člana I/2 Ustava BiH. Međutim, Ustavni sud smatra da su odredbe člana 3 st. 2 i 4 i člana 11 Zakona o izmjenama i dopunama Izbornog zakona Republike Srpske u skladu sa čl. I/2 i III/3b) Ustava BiH, budući da sadržaj tih odredaba slijedi opšte principe utvrđene Izbornim zakonom $\mathrm{BiH}$ kao „odlukom institucija Bosne i Hercegovine“, čime se ne dovodi u pitanje poštovanje principa vladavine prava.

U konkretnom slučaju, Ustavni sud smatra da je nesporno da Izborni zakon BiH predstavlja „odluku institucija Bosne i Hercegovine“ u smislu člana III/3b) Ustava $\mathrm{BiH}$, te da se tim zakonom, između ostalog, utvrđuju principi na kojima moraju da budu zasnovani izborni zakoni i propisi na ostalim nivoima vlasti. Naravno, Ustavni sud je u potpunosti svjestan da je Ustavom BiH

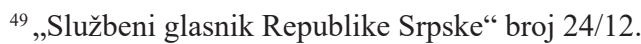


njegova nadležnost ograničena na ispitivanje ustavnosti zakona, odnosno da Ustav $\mathrm{BiH}$ ne propisuje mogućnost da Ustavni sud ispituje zakonitost entitetskih zakona u odnosu na zakone koje donosi Bosna i Hercegovina. Stoga je, u konkretnom slučaju, vodeći se svojim već zauzetim stavovima o neophodnosti da se poštuju „obaveze koje se entitetima ili drugim administrativnim jedinicama Bosne i Hercegovine nalažu odredbama državnih zakona“, Ustavni sud ustavnost osporenog zakona ispitao isključivo u svjetlu poštovanja obaveza i principa utvrđenih Izbornim zakonom BiH, kao „odlukom institucije Bosne i Hercegovine" s ciljem sprovođenja fer i demokratskih izbora na cijeloj teritoriji Bosne i Hercegovine.

Ustavni sud zapaža da je Izborni zakon BiH eksplicitno propisao minimum šest višečlanih izbornih jedinica, te da je utvrdio koje su to višečlane izborne jedinice, ali samo dok entiteti svojim zakonima ne osnuju višečlane izborne jedinice. $\mathrm{Na}$ bazi ovako utvrđenih principa u Izbornom zakonu BiH, Ustavni sud smatra da entitetski zakonodavac ima obavezu da svake četiri godine preispituje izborne jedinice i broj mandata koji su dodijeljeni svakoj izbornoj jedinici, u skladu s principima propisanim Izbornim zakonom BiH, ali da nema bilo kakvog ograničenja u odnosu na propisivanje većeg broja višečlanih izbornih jedinica od minimuma koji propisuje Izborni zakon BiH. Naravno, entitetski zakonodavac mora da vodi računa da ovo bude u skladu s „demokratskim principima, a naročito proporcionalnošću između broja mandata i broja birača upisanih u Centralni birački spisak“.

U vezi s ovim, Ustavni sud zapaža da je Narodna skupština Republike Srpske, članom 12 osporenog zakona, direktno ugradila u svoj Izborni zakon principe iz člana 11.9 Izbornog zakona $\mathrm{BiH}$, odnosno da je preuzela principe geografskog ograničenja i proporcionalnosti tako što ih je ugradila u osporeni zakon. Imajući u vidu navedeno, Ustavni sud smatra da činjenica da je članom 11 osporenog zakona propisan veći broj višečlanih izbornih jedinica od minimuma koji je propisao Izborni zakon BiH, ne može da vodi zaključku da je tom odredbom osporenog zakona prekršen neki od relevantnih principa iz Izbornog zakona $\mathrm{BiH}$, tim prije što su ti principi direktno preuzeti u osporeni zakon.

Odluka o dopustivosti i meritumu broj U-14/12

(Ustav Republike Srpske, Ustav Federacije BiH i Izborni zakon BiH)

Ustavni sud zaključuje da su odredbe člana 80 stav 2 tačka 4 (tačka 1 stav 2 Amandmana LXXXIII) i člana 83 stav 4 (tačka 5 Amandmana XL dopunjena 
Miodrag N. Simović, Milena Simović: Izborno zakonodavstvo u Bosni i Hercegovini u kontekstu prakse...

tačkom 4 Amandmana LXXXIII) Ustava Republike Srpske, člana IV.B.1 člana 1 stav 2 (dopunjen Amandmanom XLI) i člana IV.B. 1, člana 2. st. 1 i 2 (izmijenjen Amandmanom XLII) Ustava Federacije Bosne i Hercegovine), te čl. 9.13, 9.14, 9.16 i 12.3 Izbornog zakona u suprotnosti sa članom II/4 Ustava BiH i članom 1 Protokola broj 12 uz Evropsku konvenciju. Osporene odredbe 9.15, 12. 1 i 12.2 Izbornog zakona BiH u skladu sa članom II/4 Ustava BiH i članom 1 Protokola broj 12 uz Evropsku konvenciju.

\section{Odluka o dopustivosti i meritumu broj U-23/14 (Izborni zakon BiH)}

Ustavni sud zaključuje da odredba Potpoglavlja B člana 10.12 stav 2 u dijelu „Svakom konstitutivnom narodu se daje jedno mjesto u svakom kantonu“ i odredbe Poglavlja 20, Prelazne i završne odredbe člana 20.16 A stav 2 tač a-j Izbornog zakona nisu u skladu sa članom I/2 Ustava BiH, zato što očito impliciraju da pravo na demokratsko odlučivanje isključivo legitimnim političkim predstavljanjem - neće biti utemeljeno na demokratskom izboru delegata $u$ Dom naroda Federacije BiH onog konstititutivnog naroda koje predstavlja i čije interese zastupa. To je suprotno principu konstitutivnosti, odnosno ravnopravnosti bilo kojeg od konstitutivnih naroda. Ustavni sud ocjenjuje da odredbe Potpoglavlja B čl. 10.10, 10.12 u preostalom dijelu, 10.15 i 10.16 Izbornog zakona nisu suprotne članu I/2 Ustava BiH.

Ustavni sud nalazi da je izbor delegata u Dom naroda Federacije $\mathrm{BiH}$ kombinacija neposrednih i posrednih izbora. Naime, delegate Doma naroda biraju posredno kantonalne skupštine iz reda svojih delegata koji su izabrani na neposrednim - opštim izborima tajnim glasanjem na cijeloj teritoriji Federacije kada svaki birač, bez obzira na nacionalnost i bez obzira kojem konstitutivnom narodu pripada, ima pravo glasati za bilo kojeg kandidata sa izborne liste političkog subjekta. Ustavni sud uočava da član 10.12 stav 2 Izbornog zakona u dijelu: „Svakom konstitutivnom narodu se daje jedno mjesto u svakom kantonu“ i član 20.16A Izbornog zakona (određivanje po jednog delegata iz svakog konstitutivnog naroda za svaki kanton) daju mogućnost pripadniku konstitutivnog naroda da bude izabran u Dom naroda čak i u krajnjem, ali mogućem slučaju da je ta osoba jedini pripadnik nekog od konstitutivnih naroda $\mathrm{u}$ jednom od kantona, pod uslovom da je izabrana u zakonodavno tijelo tog kantona. Dakle, tog delegata na neposrednim izborima izabrali su pripadnici drugog konstitutivnog naroda i u tom zakonodavnom tijelu takođe su ga izabrali pripadnici drugog konstitutivnog naroda. 
Ustavni sud podsjeća da je u svojoj ranijoj praksi već iznio stanovište da nije pitanje ustavnosti neodgovarajuća implementacija određenih zakonskih rješenja ukoliko su ta rješenja, sama po sebi, u skladu sa Ustavom $\mathrm{BiH}$. U takvim situacijama, u slučaju zloupotrebe u implementaciji zakonskih odredbi - postoje drugi odgovarajući mehanizmi zaštite. Međutim, u konkretnom slučaju se ne radi o takvoj situaciji, već o situaciji da su navedene odredbe, same po sebi, u njihovoj implementaciji suprotne Ustavu BiH. Naime, ako se ima u vidu da ove odredbe daju mogućnost pripadniku konstitutivnog naroda da bude izabran u Dom naroda čak i u krajnjem, ali mogućem slučaju da je ta osoba jedini pripadnik nekog od konstitutivnih naroda u jednom od kantona, pod uslovom da je izabrana u zakonodavno tijelo tog kantona na neposrednim izborima, a da je nakon toga ne biraju pripadnici tog konstitutivnog naroda u Dom naroda - više je nego očito da navedene odredbe omogućavaju da predstavnicima jednog konstitutivnog naroda u zakonodavnom tijelu kantona legitimitet daju predstavnici drugog konstitutivnog naroda, odnosno jedan takav delegat ima isti „kapacitet“ u Domu naroda kao i bilo koji drugi delegat kojeg su izabrali pripadnici, odnosno delegati samo iz tog konstitutivnog naroda. Dakle, očito je da navedene odredbe impliciraju da pravo na demokratsko odlučivanje isključivo legitimnim političkim predstavljanjem neće biti zasnovano na demokratskom izboru delegata u Dom naroda Federacije $\mathrm{BiH}$ onog konstitutivnog naroda koji predstavlja i čije interese zastupa.

Nadalje, u situaciji kada im na neposrednim izborima u pretežnom dijelu legitimitet mogu dati pripadnici drugih konstitutivnih naroda, čak i u slučaju da zakonodavno tijelo kantona ima više delegata iz reda određenog konstitutivnog naroda, navedene odredbe krše Ustav BiH. U skladu s navedenim, Ustavni sud nalazi da odredbe člana 10.12 stav 2 u dijelu: „Svakom konstitutivnom narodu se daje jedno mjesto u svakom kantonu“ i odredbe člana 20.16A Izbornog zakona ne samo da se ne zasnivaju na jasno preciziranim kriterijumima koji trebaju dovesti do što potpunijeg predstavljanja svakog od tri konstitutivna naroda u Federaciji $\mathrm{BiH}$ - nego očito impliciraju da pravo na demokratsko odlučivanje isključivo legitimnim političkim predstavljanjem neće biti zasnovano na demokratskom izboru delegata u Dom naroda Federacije BiH onog konstitutivnog naroda koji predstavlja i čije interese zastupa. Ustavni sud nalazi da je izneseno suprotno principu konstitutivnosti, odnosno ravnopravnosti bilo kojeg od konstitutivnih naroda, a time i suprotno Ustavu $\mathrm{BiH}$, konkretno članu I/2 Ustava $\mathrm{BiH}$. 
Miodrag N. Simović, Milena Simović: Izborno zakonodavstvo u Bosni i Hercegovini u kontekstu prakse...

Odluka o dopustivosti i meritumu broj U-6/17

(Izborni zakon BiH)

Odbijen je zahtjev 26 poslanika u Predstavničkom domu Parlamenta Federacije $\mathrm{BiH}$ za ocjenu ustavnosti člana 3.15 Izbornog zakona $\mathrm{BiH}$. Utvrđuje se da je član 3.15 Izbornog zakona BiH u skladu s čl. I/2, II/1, II/2, II/3, II/4 i II/5 Ustava BiH, čl. 14 i 17 Evropske konvencije, čl. 25 i 26 Međunarodnog pakta, članom 3 Protokola broj 1 i članom 1 Protokola broj 12 uz Evropsku konvenciju, te članom 1 Međunarodne konvencije o ukidanju svih oblika rasne diskriminacije.

Ustavni sud podsjeća na to kako je u pogledu tumačenja pojma diskriminacije u svojoj dosadašnjoj praksi ${ }^{50}$ slijedio stav Evropskog suda prema kojem: „Jurisprudencija naročito jasno precizira da ‘diskriminacija` označava različito postupanje bez objektivnog i razumnog opravdanja prema licima koja su se našla u sličnom položaju (vidjeti tač. 42-44 i navedene izvore). Autori su koristili isti termin, diskriminacija, u članu 1 Protokola broj 12, bez obzira na razlike u širini obima između ovih odredbi, značenje ovog pojma u članu 1 Protokola broj 12 je trebalo biti identično tumačenju iz člana 14 (vidjeti Obrazloženje uz Protokol broj 12, tačka 18). Sud, prema tome, ne vidi razlog da odstupa od utvrđenog tumačenja 'diskriminacije', navedenog u tekstu, u primjeni istog pojma prema članu 1 Protokola broj 12 (u vezi sa sudskom praksom UN-ovog Komiteta za ljudska prava u pogledu člana 26 Međunarodnog pakta, odredbe koja je slična, ali ne i identična - članu 1 Protokola broj 12 uz Konvenciju“.

Slijedom navedenog, Ustavni sud je morao odgovoriti na pitanje da li osporeni član 3.15 Izbornog zakona državljane BiH u inostranstvu i izbjeglice iz $\mathrm{BiH}$, propisujući obavezu da za svaki izborni proces podnesu prijavu, a koja obaveza nije propisana i za državljane $\mathrm{BiH}$ u $\mathrm{BiH}$ - tretira različito u odnosu na državljane $\mathrm{BiH}$ u $\mathrm{BiH}$, što nema objektivno i razumno opravdanje. Imajući u vidu sve navedeno, Ustavni sud smatra da se osporenim članom 3.15 Izbornog zakona ne dovodi u pitanje ravnoteža između opšteg prava koje je nesporno priznato svim državljanima $\mathrm{BiH}$ bez obzira na to gdje žive, $\mathrm{s}$ jedne strane, i potrebe za bezbjednošću glasova i uređenjem drugih praktičnih pitanja u vezi s ostvarivanjem ovog prava, s druge strane.

\footnotetext{
${ }^{50}$ Vidi, između ostalih, citiranu odluku o dopustivosti i meritumu, broj U-14/12, stav 63.
} 
Odluka o dopustivosti broj U-3/19

(Uputstvo o izmjeni i dopuni Uputstva o postupku provedbe posrednih izbora za organe vlasti u Bosni i Hercegovini obuhvaćenih Izbornim zakonom BiH)

Odbačen je kao nedopušten zahtjev predsjedavajuće Predstavničkog doma Parlamentarne skupštine BiH za ocjenu ustavnosti Uputstva o izmjeni i dopunama Uputstva o postupku provedbe posrednih izbora za organe vlasti $u$ Bosni i Hercegovini obuhvaćenih Izbornim zakonom $\mathrm{BiH}^{51}$ - zbog nenadležnosti Ustavnog suda.

Ustavni sud zapaža da podnositeljka zahtjeva osporava legitimitet Centralne izborne komisije Bosne i Hercegovine (CIK) za donošenje spornog akta jer, kako tvrdi, CIK za to nije imao ovlašćenje u odredbama Izbornog zakona. Podnositeljka zahtjeva tvrdi da zbog činjenice da Aneks VII nije sproveden, nije bilo mjesta za primjenu odredbe člana 10.12 Izbornog zakona, a na šta upućuje član 20.16A Izbornog zakona. S druge strane, Ustavni sud, takođe, zapaža da podnositeljka zahtjeva izražava nezadovoljstvo što CIK prilikom utvrđivanja preliminarnog broja delegata - „svakom konstitutivnom narodu se daje jedno mjesto u svakom kantonu“ - nije poštovao Odluku Ustavnog suda, broj U-23/14, pa je, prema ocjeni podnositeljke zahtjeva, takav pristup CIK-a u direktnoj suprotnosti s citiranom odlukom jer je CIK morao poštovati odluku Ustavnog suda. Cijeneći ove prigovore, Ustavni sud, prije svega, zapaža da se ovim navodima nelegitimnost CIK-a zapravo dovodi u vezu s neizvršenjem odluke Ustavnog suda. Ustavni sud ponovo naglašava da se u okolnostima konkretnog slučaja ne radi o izvršenju Odluke broj U-23/14, o čemu se Ustavni sud ranije u ovoj odluci već detaljno izjasnio i naglasio da CIK nije bio ni ovlašćen da sprovodi citiranu odluku.

Ustavni sud smatra da je u nadležnosti redovnih sudova da provjere da li je administrativni propis, kao što su uputstva CIK-a, u skladu s Izbornim zakonom i Ustavom Federacije BiH.

\section{Vitalni nacionalni interes}

U Odluci Ustavnog suda o dopustivosti i meritumu, broj U-3/17, utvrđeno je da Izjava Kluba delegata bošnjačkog naroda u Domu naroda Parlamentarne skupštine BiH o destruktivnosti po vitalni interes bošnjačkog naroda u Bosni i Hercegovini u Prijedlogu Zakona o izmjenama i dopunama Izbornog zakona $\mathrm{BiH}$, broj $02-02-1-1133 / 17$ od 28. aprila 2017. godine, ispunjava uslove

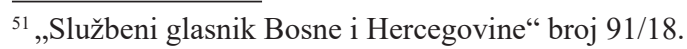


Miodrag N. Simović, Milena Simović: Izborno zakonodavstvo u Bosni i Hercegovini u kontekstu prakse...

proceduralne ispravnosti iz člana IV/3f) Ustava BiH. Utvrđuje se da prijedlogom ovog zakona nije povrijeđen vitalni interes bošnjačkog naroda u Bosni i Hercegovini.

\section{Apelaciona nadležnost}

Odluka o dopustivosti i meritumu broj AP-2679/06 od 29. septembra 2006. godine (arbitrarnost u potvrđivanju kandidature na izborima)

Ustavni sud je utvrdio da je povrijeđeno apelantovo pravo na pravično suđenje iz člana II/3e) Ustava i člana 6 stav 1 Evropske konvencije, jer je Sud BiH arbitrarno primijenio član 4.2 stav 1 tačka 2 Izbornog zakona BiH, utvrdivši da je CIK pravilno odbio potvrdu kandidature sporne kandidatkinje za koju je utvrđeno da nije bila u Centralnom biračkom spisku na dan objavljivanja izbora. Arbitrarnost se očitovala u zaključku Suda BiH da je jedini relevantan dokument za evidentiranje u Centralni birački spisak „CIPS-ova lična karta“ iako Izborni zakon BiH ne sadrži takvu odredbu, a druge odredbe Izbornog zakona $\mathrm{BiH}$ jasno definišu koje se sve javne evidencije koriste za stvaranje i ažuriranje Centralnog biračkog spiska, kao što predviđaju i jasnu obavezu CIK-a da vodi i ažurira Centralni birački spisak.

Odluka o dopustivosti i meritumu broj AP-4144/16 od 10. novembra 2016. godine (navodna diskriminacija u ostvarivanju prava da se bude biran)

Ustavni sud zaključuje da nije povrijeđeno pravo iz člana 1 Protokola broj 12 $\mathrm{u}$ vezi s pasivnim biračkim pravom iz člana 13.7 Izbornog zakona u vezi sa članom 4.4 Izbornog zakona kada je apelantu bilo omogućeno da se, u skladu sa članom 4.4 Izbornog zakona, prijavi za učešće na izborima za načelnika opštine na kojim je, u skladu sa članom 13.7 Izbornog zakona, svim biračima upisanim u Centralni birački spisak za osnovnu izbornu jedinicu Srebrenica bez diskriminacije i pod jednakim uslovima bilo omogućeno da u skladu sa Izbornim zakonom biraju načelnika.

Odluka o dopustivosti i meritumu broj AP-5745/10

(kršenje pravila ponašanja u izbornoj kampanji)

Ustavni sud zapaža da iz obrazloženja osporenih odluka proizlazi da je CIK, u skladu s ovlaštenjima iz člana 6.6 stav (1) Izbornog zakona BiH i člana 
115 stav (1) Zakona o upravnom postupku, pokrenula postupak utvrđivanja apelantove odgovornosti nakon što je BHT1 podnijela prijavu da je apelant, učestvujući u debatnoj emisiji izbornog programa BHT1, na izuzetno neprimjeren, drzak i agresivan način zloupotrijebio vrijeme i prostor u javnom mediju, čime je ugrozio objektivno informiranje javnosti i sprječavao ostale goste da ravnopravno učestvuju u emisiji. Iz priloženih dokaza proizlazi da je CIK na temelju prijave BHT1 donijela zaključak o pokretanju postupka, za šta je imala zakonsku osnovu utemeljenu na odredbi člana 6.6 stav (1) Izbornog zakona $\mathrm{BiH}$.

Ustavni sud zapaža da je na temelju provedenih dokaza, CIK nesporno utvrdila da je apelant svojim postupcima u debatnoj emisiji BHT1 prekršio pravila ponašanja u izbornoj kampanji iz člana 7.3 stav (1) tačka 3) Izbornog zakona $\mathrm{BiH}$, zbog čega mu je na osnovu člana 6.7 tačka 1 i primjenom člana 19.9 stav (4) navedenog zakona - izrečena novčana kazna u iznosu od 2.500,00 KM. Apelantove prigovore da je bio spriječen da na usmenoj raspravi iznese svoju odbranu, te da predlaže dokaze, Ustavni sud smatra neosnovanim jer tako što ne proizlazi iz dostavljenih dokaza u spisu. Ustavni sud zapaža da se apelant odazvao pozivu CIK-e da prisustvuje javnoj raspravi, na kojoj se apelant pojavio lično u pratnji svog punomoćnika. Iz priloženih dokaza takođe proizlazi da je apelant imao mogućnost da, u skladu sa Zakonom o upravnom postupku, sam da izjavu, ali da tu mogućnost apelant tokom javne rasprave nije koristio, niti se na bilo koji način usprotivio izjavama koje je u njegovo ima dao njegov punomoćnik.

Isto tako, iz priloženih dokaza je vidljivo da apelant nije predlagao nikakve dokaze, niti je tokom postupka u tome na bilo koji način bio spriječen, pa u takvim okolnostima Ustavni sud smatra da u konkretnom slučaju nije prekršeno pravo na jednakopravnost strana u postupku na šta apelant neosnovano ukazuje. Činjenica da apelant tokom postupka nije iskoristio prava koja mu je pružao Zakon o upravnom postupku - ne vodi zaključku da su apelantu u postupku uskraćene garancije koje pruža člana 6 stav 1 Evropske konvencije.

Zatim, Ustavni sud zapaža da apelant u suštini ponavlja navode koje je tokom postupka već isticao i o kojima su se i CIK i Sud BiH u obrazloženjima svojih odluka dovoljno jasno i argumentovano izjasnili, a data obrazloženja se u okolnostima konkretnog slučaja ne čine proizvoljnim. Uz to, apelant ni u apelaciji nije ponudio relevantne dokaze kojim bi potkrijepio iscrpne navode iz apelacije. Cijeneći postupak u cjelini, Ustavni sud smatra da je postupak proveden u skladu s garancijama koje pruža člana 6 stav 1 Evropske konvencije, te stoga Ustavni sud zaključuje da osporenim odlukama nije prekršeno 
Miodrag N. Simović, Milena Simović: Izborno zakonodavstvo u Bosni i Hercegovini u kontekstu prakse...

apelantovo pravo na pravično suđenje iz člana II/3e) Ustava $\mathrm{BiH}$ i člana 6 stav 1 Evropske konvencije.

Odluka o dopustivosti i meritumu, broj AP-66/15 od 10. februara 2015. godine (Izjašnjavanje na izborima - nacionalna pripadnost)

Apelanti, u suštini, ukazuju na nezakonito postupanje CIK-a i Suda BiH prilikom odbijanja prijedloga za ovjeru kandidatskih lista zbog činjenice što su se za Opšte izbore 2014. godine izjasnili kao Srbi, što je bilo njihovo legitimno pravo, pogotovo ako se uzme u obzir da se radi o drugom izbornom ciklusu, a ne aktuelnom, kako su to, prema navodima apelanata, pogrešno utvrdili CIK i Sud BiH. Ističu da nijedan propis ne zabranjuje licu da se izjasni kako želi i kako se osjeća, te da CIK i Sud BiH nisu imali uporište u Izbornom zakonu, niti u Uputstvu da apelantima uskrate pravo na ovjeru kandidatskih lista.

Ustavni sud zaključuje da osporenim odlukama nije došlo do kršenja prava apelanata iz člana 3 Protokola broj 1 uz Evropsku konvenciju i člana 25 Međunarodnog pakta kada su mjere koje su preduzeli CIK i Sud BiH bile u skladu sa zakonom, legitimne i proporcionalne cilju kojem se težilo. Takođe, nije došlo do kršenja prava iz člana II/2g) Ustava BiH i člana 9 Evropske konvencije, jer Ustavni sud ne može zaključiti na koji način se osporenim odlukama pokreće bilo koje pitanje u vezi sa uživanjem ovih garancija. Uz to, Ustavni sud zaključuje da nije bilo kršenja prava iz člana II/4 Ustava $\mathrm{BiH}$ i člana 14 Evropske konvencije u vezi sa pravom iz člana 3 Protokola broj $1 \mathrm{uz}$ Evropsku konvenciju i člana 25 Međunarodnog pakta kada su se apelanti neutemeljeno pozvali na kršenje navedenog prava i praksu Evropskog suda, pri čemu iz osporenih odluka ne proizlazi da su apelanti u predmetnim postupcima na bilo koji način bili diskriminisani. Isto tako, Ustavni sud zaključuje da osporenim odlukama nije došlo do kršenja prava iz člana 26 Međunarodnog pakta, te člana II/1, II/2 i II/6 Ustava BiH kada apelanti, u suštini, kršenje navedenih prava temelje na istim razlozima na kojim su temeljili navode o zabrani diskriminacije u vezi sa pravom na slobodne izbore, a Ustavni sud je zaključio da u tom pravcu nije bilo kršenja prava apelanata. 
Odluka o dopustivosti i meritumu, broj AP-2609/16

(ovjera kandidatskih listi u odnosu na član 3 Protokola broj 1 uz Evropsku konvenciju - ratione materiae nedopustivi navodi)

Ustavni sud je mišljenja da u smislu člana 3 Protokola broj 1 uz Evropsku konvenciju opštinska vijeća, skupštine grada, gradska vijeća, kao i izbor za opštinskog gradonačelnika nisu zakonodavna tijela u smislu citiranog člana Evropske konvencije. Kako slijedi iz Zakona o lokalnoj samoupravi, nadležnosti ovih tijela su regulisane čl. 12, 13 i 14, a odnose se na: a) regulatorne radnje i upravljanje opštinom, b) zatim na pružanje usluga i obavljanja specifičnih funkcija u oblasti kulture, obrazovanja, sporta, zdravstva i socijalne zaštite, civilne zaštite, informacija, zanatstva, turizma, ugostiteljstva i zaštite okoline i c) u oblasti urbanističkog planiranja i stambeno-komunalnih djelatnosti i druge nadležnosti utvrđene Zakonom o lokalnoj samoupravi, iz čega proizlazi da navedena tijela mogu donositi samo provedbene propise $i$ da se ne mogu smatrati zakonodavnim tijelom u smislu Evropske konvencije. Stoga, ovo pravo se ne odnosi na njih i Ustavni sud smatra da nema potrebe proširivati domašaj navedenog člana na izbore za opštinska vijeća, gradska vijeća, skupštine gradova, gradonačelnike, opštinske načelnike, kao i druga tijela i organe za koje se raspisuju lokalni izbori. Stoga, slijedi da su navodi apelacije ratione materiae inkompatibilni (i) u odnosu na pravo na slobodne izbore iz člana 3 Protokola broj 1 uz Evropsku konvenciju.

\section{Član 14 Evropske konvencije}

U Odluci broj AP-66/15, u vezi s navodima apelanata iznesenim u tom predmetu, Ustavni sud je ukazao da je Evropski sud u predmetu Sejdić i Finci protiv Bosne i Hercegovine, između ostalog, zaključio da dugotrajna nemogućnost aplikanata da se kandiduju za Dom naroda Parlamentarne skupštine $\mathrm{BiH}$ nema objektivno i prihvatljivo opravdanje, te da je, stoga, došlo do kršenja člana 14 u vezi sa članom 3. Protokola broj 1 uz Evropsku konvenciju. Navedeni stav je Evropskom sudu bio osnov da u predmetu Zornić protiv Bosne i Hercegovine dođe do istog zaključka.

\section{Zaključak}

Nema sumnje da je za parlamentarni proces i zaštitu izbornih prava građana od posebnog značaja i djelotvorno rešavanje izbornih sporova. Prema 
pozitivnom zakonodavstvu Bosne i Hercegovine, pravna funkcija rješavanja izbornih konflikata tokom izbornog postupka u cjelini je stavljena u zadatak redovnom pravosuđu.

Da bi izbori bili demokratski, biračko pravo treba da bude opšte i jednako. Na izborima se mora obezbijediti učešće različitih segmenata društva, a sam sistem sprovođenja izbora i utvrđivanja njihovih rezultata treba da bude pravičan. Suštinski značaj za demokratski karakter izbora ima slobodno izjašnjavanje građana, a njega nema bez opozicije i slobodnih medija. Budući da su pravno uređeni, izbori, uz sudsku zaštitu ustavnosti i zakonitosti, imaju i značaj za vladavinu prava. „Odabir“ izbornog sistema je važan i u procesu implementacije osnovnih ustavnih principa u sistemu predstavničke demokratije.

Zahtjev koji se odnosi na jednako pravo glasa ne podrazumijeva tačnu jednakost u važnosti, ili djelovanju, svakog glasa birača. To bi bio nedostižni ideal. Suština tog zahtjeva je da bi svaki glasač trebao da ima isti broj glasova i da bi svaki glas trebao da ima približno istu vrijednost, premda precizna jednakost djelovanja može da bude nedostižna prema nekim sistemima glasanja, čak i ako bi broj birača u svakoj izbornoj jedinici trebao da bude jednak; naprimjer, u praksi, glasovi mogu da imaju različitu važnost prema nekim oblicima proporcionalne zastupljenosti, a glasovi dodijeljeni istoj partiji mogu da imaju različito djelovanje $u$ različitim izbornim jedinicama u izbornim sistemima koji koriste prostu većinu (većinski izborni sistem). Precizna jednakost u broju glasača u svakoj izbornoj jedinici je nedostižna u praksi. Različite poteškoće utiču na povlačenje granica izbornih jedinica. Neke od tih su geografske, druge su administrativne.

Sve ono što može da se postigne jeste da ne bi trebalo da bude pretjeranih nejednakosti u veličini biračkog tijela i važnosti koja se daje pojedinim glasovima u različitim izbornim jedinicama. Nju su priznali i autori Međunarodnog pakta (Nowak, 1993: 448). Evropski sud je to takođe prihvatio prilikom tumačenja riječi ,jednako pravo glasa“ iz člana 3 Protokola broj 1 uz Evropsku konvenciju ${ }^{52}$. Evropski sud priznaje ograničenja prava i pita se da li je bilo proizvoljnosti ili neproporcionalnosti i da li je tim ograničenjem došlo do miješanja u slobodno izražavanje volje biračkog tijela, $u$ donošenju ocjene $u$ svjetlu političkih uslova u državi o kojoj se radilo ${ }^{53}$.

\footnotetext{
${ }_{52}^{52}$ Vidi Matthieu-Mohin protiv Belgije, serija A, br. 113, presuda od 2. marta 1987., stav 54.

${ }^{53}$ Vidi, generalno, Ždanoka protiv Latvije, aplikacija broj 58278, Izvještaji 2006-IV (Veliko vijeće) i Adamsons protiv Latvije, aplikacija broj 3669/03, presuda od 24. juna 2008., stav 111.
} 


\section{Literatura}

Breneselović, L. (2012). „Crtice sociološkopravne analize našeg izbornog postupka“, Zbornik radova Izbori u domaćem i stranom pravu, Institut za uporedno pravo, Beograd.

Ćeranić, J. (2009). „Ratifikacija Lisabonskog ugovora - reforma Evropske unije: bilans i perspektive“", Strani pravni život, broj 3, Institut za uporedno pravo, Beograd.

Ćeranić, J. (2012). „Izbori za evropski parlament“, Zbornik radova Izbori u domaćem $i$ stranom pravu, Institut za uporedno pravo, Beograd.

Ćirić, J. (2008). „Problemi političke korupcije“, Sociološki pregled, broj 4, Beograd.

Ćirić, J. (2012). „Političke partije kao generator korupcije“, Zbornik radova Izbori u domaćem $i$ stranom pravu, Institut za uporedno pravo, Beograd.

Čok, V. (1989). „Ravnopravnost žene u sistemu prava čoveka“, Zbornik Pravnog fakulteta u Zagrebu, broj 59, Zagreb.

Dimitrijević, V., Paunović, M. (1997). Ljudska prava, COLPI i Beogradski centar za ljudska prava, Beograd.

Douglas, J.A., Mazo, E.D. (2016). Election Law Stories, Ed. Foundation Press.

Đukić-Veljović, Z. (1995). Ogledi o političkom predstavništvu i izborima, Pravni fakultet u Beogradu, Beograd.

Đukić-Veljović, Z., N. Vuković, N. (2006). „Ustavnopravna zaštita izbornog prava“, Arhiv za pravne i društvene nauke, broj 3-4, Beograd.

Đurić, V. (2012). Izbori i delotvorno učešće nacionalnih manjina u javnim poslovima, Zbornik radova „Izbori u domaćem i stranom pravu“, Institut za uporedno pravo, Beograd.

Farell, D.M. (2001). Electoral Systems: A Comparative Introduction, Palgrave.

Gallagher M., Laver, M., Mair, P. (2001). Representative Government in Modern Europe, McGraw Hill International Edition.

Goati, V. (2004). Partije i partijski sistem Srbije, OGI, Niš.

Goati, V. (2007). „Parlamentarizam i partijski sistem Srbije“, u Dileme i izazovi parlamentarizma (V.Pavlović, S.Orlović, ur.), Konrad Adenauer Stiftung, Fakultet političkih nauka, Beograd.

Heitshusen, V. (2009). Change and Lobbying, Chicago, University of Chicago Press.

Horowitz, D.L. (2003). “Electoral Systems: A Primer for Decision Makers”, Journal of Democracy, Vol. 14, No. 4.

Jovanović, S. (1924). Država, Geca Kon, Beograd.

Jovanović, M. (2004). Izborni sistemi postkomunističkih država, „Službeni list SCG“, Beograd.

Jovičić, K., Plavšić-Nešić, A. (2012). „Ljudska i izborna prava“, Izbori u domaćem i stranom pravu, Institut za uporedno pravo, Beograd.

Krutz, G., Waskiewicz, S. (2017). American Government, Suwanee, 12th Media Services.

Lowenstein, D.H., Hasen,R.L., Tokaji,D.P. (2012). Election Law: Cases and Materials, 5th Ed. Carolina Press.

Manojlović-Andrić, K. (2007). „Zaštita ustavnih prava pripadnika nacionalnih manjina u izbornom sporu“, Bilten Vrhovnog suda Srbije, Beograd, broj 3.

Marinković, T. (2011). „Politika u granicama Ustava - o načelima predstavničke demokratije u jurisprudenciji Ustavnog suda Srbije“, Zbornik radova Pravnog fakulteta u Nišu i Pravnog fakulteta u Kragujevcu, tematski broj Ustav Republike Srbije - pet godina posle (2006-2011), Niš.

Marković R. (2008). Ustavno pravo i političke institucije, Službeni glasnik, Beograd.

Masclet, J.C. (1989). Droit électoral, Presses Universitaires de France, Paris. 
Miodrag N. Simović, Milena Simović: Izborno zakonodavstvo u Bosni i Hercegovini u kontekstu prakse...

Matić, M. (1974). Političko predstavljanje: razmatranja u oblasti političke teorije, Beograd. Milenković, D. (2012). „Organi nadležni za sprovođenje izbora - pojam i oblici izborne administracije (uprave) u Srbiji“, Zbornik radova Izbori u domaćem i stranom pravu, Institut za uporedno pravo, Beograd.

Milošević, Z. (2007). „Političke stranke i korupcija“, Politička revija, Beograd, 1.

Mratović, V. (1971). Hrestomatija političle znanosti, Zagreb.

Mrvić-Petrović, N., Ćirić, J. (2004). Sukob javnog i privatnog interesa u trouglu moći, novca i politike, Beograd.

Nenadić, B. (2008). Ustavni sud u Ustavu Republike od 2006, Beograd.

Nenadić, B. (2008). „O parlamentarnom mandatu: primer Republike Srbije“, Anali Pravnog fakulteta u Beogradu, 2, Beograd.

Nenadić, B., Vlatković, M. (2003). „Prestanak mandata narodnog poslanika zbog prestanka članstva u političkoj stranci ili koaliciji na čijoj je listi izabran“, Glasnik advokatske komore Vojvodine, Novi Sad, broj 3.

Nikolić, O. (2012). „Glasanje putem pošte sa posebnim osvrtom na glasanje dijaspore - uporednopravna analiza“, Zbornik radova Izbori u domaćem i stranom pravu, Institut za uporedno pravo, Beograd.

Norris, P. (1997). "Choosing Electoral Systems: Proportional, Majoritarian and Mixed Systems", International Political Science Review, Vol. 18, No. 3.

Nowak, M. (1993). U.N. Covenant on Civil and Political Rights, CCPR Commentary, N.P. Engel, Publisher.

Nowak, M. (2005). U.N. Covenant on Civil and Political Rights, CCPR Commentary, N.P. Engel, Publisher.

Orlović, S. (2010). Politikološki ogledi, Službeni glasnik, Beograd.

Pajvančić, M. (1996). „Odluke ustavnih sudova u izbornim sporovima“, Pravni život, broj 12, Beograd.

Pajvančić, M. (1997). Izbori - pravila i proračuni, Naša borba, Novi Sad.

Pajvančić, M. (1998/1999). „Zaštita sloboda i prava građana“, Zbornik radova Pravnog fakulteta u Novom Sadu, br. 1-3, Novi Sad.

Pajvančić, M. (2003). Uvod u izborne sisteme, Niš.

Pajvančić, M. (2003a). „Proporcionalni izbori, slobodan mandat i zaštita statusa poslanika“, Glasnik advokatske komore Vojvodine, broj 3, Novi Sad.

Pajvančić, M. (2005). Parlamentarno pravo, Fondacija Konrad Adenauer, Beograd.

Pajvančić, M. (2005). Ustavno i pravosudno organizaciono pravo, Beograd.

Pajvančić, M. (2007). Ustavno pravo, Pravni fakultet, Novi Sad.

Pajvančić, M. (2008). Izborno pravo, Pravni fakultet, Novi Sad.

Pajvančić, M. (2012). „Pasivno biračko pravo (poslanička sposobnost)“, Zbornik radova Izbori $u$ domaćem i stranom pravu, Institut za uporedno pravo, Beograd.

Pajvančić, M., Beljanski, S. (2003). Ustavno pravo i pravosudno organizaciono pravo, Beograd.

Pajvančić, M.,Vukčević, M. (2012). Ustavno pravo, Podgorica.

Pejić, I. (2008). „Koncept narodnog predstavništva i kontroverze o parlamentarnom mandatu u srpskom ustavu“, NSPM, posebno izdanje Ustav i iskušenja, broj 2.

Pejić, I. (2012). „Izborna lista u srazmernom predstavništvu - iskustvo Srbije“, Zbornik radova „Izbori $u$ domaćem $i$ stranom pravu“, Institut za uporedno pravo, Beograd.

Petrov, V. (2012). „Zakon o izmenama i dopunama zakona o izboru narodnih poslanika od 2011 - da li je poslanički mandat konačno slobodan? Zbornik radova Izbori u domaćem $i$ stranom pravu, Institut za uporedno pravo, Beograd. 
Popović, D. (2011). „Uticaj Evropske konvencije o ljudskim pravima na srpsko pravo“, Pravni zapisi, Pravni fakultet Univerziteta Union u Beogradu, broj 2, Beograd.

Prlja, D. (2012). „Elektronsko glasanje“, Zbornik radova Izbori u domaćem i stranom pravu, Institut za uporedno pravo, Beograd.

Simić, M., Stradner, I. (2012). „Izbori u zemljama trećeg sveta“, Zbornik radova Izbori u domaćem i stranom pravu, Institut za uporedno pravo, Beograd.

Smith, R., van der Anken, C., The Essentials of Human Rights, Hodder Arnold, London, 2005,

Stefanović, J. (1956). Ustavno pravo FNRJ i komparativno, Školska knjiga, Zagreb.

Stojiljković, Z. (2008). Partijski sistem Srbije, Beograd.

Stojiljković, Z. (2011). „Partijske ideologije, Evropski politički prostor i Srbija“, FPN Godišnjak, broj 6.

Stojanović, D. (1999). Pravni položaj poslanika na primerima Francuske, Austrije, Nemačke i Jugoslavije, Niš.

Stojanović, D. (2003). „O ustavnost odredaba člana 88 st. 1 i 9 Zakona o izboru narodnih poslanika“, Glasnik advokatske komore, Novi Sad, broj 3.

Stojanović, D. (2012). „Izborni sporovi u nadležnosti ustavnih sudova“, Zbornik radova Izbori u domaćem i stranom pravu, Institut za uporedno pravo, Beograd.

Todorović, M. (2002). Izborne manipulacije, CESID, Beograd.

Tomson, D. (2007). Politička etika i javna služba, Službeni glasnik, prevod sa engleskog, Beograd.

Vasović, V., Goati, V. (1993). Izbori i izborni sistemi, IBN Centar i NIP "Radnička štampa", Beograd.

Vukadinović, S. (2012). „Odnos građana i narodnih poslanika nakon izbora“, Zbornik radova Izbori u domaćem i stranom pravu, Institut za uporedno pravo, Beograd.

Vuković, N. Ustavne granice „,partijskog“ mandata, dostupno na www.nspm.rs/srb ijamedju-ustavima/ustavne-granice-qpartijskogq-mandata.html

Vuković, M., Pajvančić, M. (2019). Parlamentarno pravo, Konrad-Adenauer-Stiftung, Beograd.

\title{
Electoral Legislation in Bosnia and Herzegovina in the Context of the Case-Law of the European Court of Human Rights and the Constitutional Court of Bosnia And Herzegovina
}

\begin{abstract}
The constitutional political right of citizens is to constitute authorities in political communities through elections. Election gives legitimacy to the legislative body as the broadest directly elected representation of citizens. By the act of election, citizens directly express their trust in the government they constitute. Elections are a way of gaining or losing legitimacy. The
\end{abstract}


Miodrag N. Simović, Milena Simović: Izborno zakonodavstvo u Bosni i Hercegovini u kontekstu prakse...

possibility of citizens' participation in the election of government bodies is guaranteed by the right to vote, which presupposes the existence, above all, of a multi-party system, because in one-party system the citizens practically do not make an election, but vote in a plebiscite. However, the electoral system is part of the political system and, as a rule, shares its destiny. In doing so, an important aspect in observing the role and effect of the electoral system is the harmonization of the electoral system established by the constitution, laws and other regulations and the electoral system that actually functions in practice. This presupposes the existence of control (by bodies determined by the law) of compliance with all election principles and rules and the sanctioning of all violations that disrupt the electoral system and processes. The modern constitutional state is based on the sovereignty of the peoples and the rule of law, and the elections are the link between these two pillars of the modern state. Like any right, the right to vote can be violated, so the protection of that right is another important precondition for its realization. This issue has a broader constitutional significance, which comparative constitutional practice addresses in various ways.

The right to vote and to be elected is not an absolute right and the state is given a wide margin of appreciation in terms of how it will regulate this issue, as well as the issue of organizing and conducting the election process. The obligation of the state, arising from Article 3 of Protocol No. 1 to the European Convention for the Protection of Human Rights and Fundamental Freedoms, provides for active and passive suffrage of the people: the active right to vote and the passive right to run as a candidate. However, these rights only apply to the election of "legislative bodies". The European Court of Human Rights has consistently held that this article applies only to the election of bodies that perform a significant legislative function. Whether a body exercises sufficient legislative power to be considered a legislative body for this purpose, is a matter of assessment to be answered in the light of that body's role and its contribution to democratic law making in the context of the constitution as a whole.

Article I/2 of the Constitution of Bosnia and Herzegovina establishes that Bosnia and Herzegovina shall be a "democratic state, which shall operate under the rule of law and with free and democratic elections", from which follows the principle of the rule of law, according to which the laws and other regulations that are being passed must be harmonized with constitutional principles. In this context, it should be recalled that states enjoy a wide margin of appreciation in establishing and regulating the electoral system they will apply. There are different ways of organizing and conducting elections, and this difference is conditioned, among other things, by the political development of the country. Therefore, the legislation governing elections must be seen in the light of political development of the country in question. Furthermore, according to the general principle of democracy, the right to democratic decision-making is exercised through legitimate political representation, which must be based on the democratic choice of those it represents and whose interests it represents. In this sense, the connection between those it represents and their political representatives at all administrative-political levels is the one that enables legitimacy to the representatives of the community. Thus, only the legitimacy of representation creates the basis for real participation and decision-making.

The BiH Election Law was adopted in 2001, since when it has been amended several times, due to, among other things, the complex constitutional, institutional and political concept in Bosnia and Herzegovina. The Election Law of $\mathrm{BiH}$, under the provision of Article 1.1, prescribes elections at the state level and "determines the principles for conducting elections at all government levels in Bosnia and Herzegovina". According to various international organizations and institutions (e.g. the OSCE and the Venice Commission), the BiH Election 
Law is comprehensive and, in general, provides a solid basis for democratic elections. On the other hand, given the number and nature of the laws applicable to elections, and given the complex legal system in Bosnia and Herzegovina, the legal framework for conducting elections in Bosnia and Herzegovina can also be considered as a complex one. Namely, in addition to the Election Law of BiH, there is also the Election Law of the Republika Srpska and the Election Law of the Brčko District of $\mathrm{BiH}$, while in the Federation of $\mathrm{BiH}$ the Law on the Establishment of Election Bodies in the Federation of $\mathrm{BiH}$ was passed. Therefore, in order to conduct fair and democratic elections there is a particular need to harmonize the complex electoral legislative framework and that all the laws in this field follow basic principles and standards established by the BiH Election Law.

Key words: elections, electoral system, suffrage, constitutional political right. 